\title{
Člověk a artefakt. Téma archeologické antropologie
}

\author{
Josef Unger - Milada Hylmarová - Martin Mazáč - Miroslav Šenkýř - Miroslav Králík \\ Ústav antropologie Př́rodovědecké fakulty Masarykovy univerzity, Vinařská 5, 60300 Brno \\ Do redakce doručeno 13. března 2014; k publikaci přijato 20. června 2014
}

\section{MAN AND ARTEFACT. A THEME OF ARCHAEOLOGICAL ANTHROPOLOGY}

ABSTRACT Artefacts created by man represent enhanced means for the performance of the ancient biological functions (obtaining food, defending territory, social status presentation, reproduction, and organization of life in a social group) as they are culturally universal/indifferent; on the other hand, human cultures vary substantially in their detailed forms due to differences in technology, religion, symbolism, fashion, etc. One of the themes of archaeological anthropology is the relationship between human and artefact that can be expressed by tripartite interactions among artefact, human and purpose. Artefact is affected by the properties of the used raw material and its availability in natural environment; but at the same time, it directly reflects features/properties of the user, person or a human society (body size, age, gender, health status, time constraints, technological level, raw material resources, tradition); and, to the extent required, it must also respect the purpose for which it was made and/or is used (working/utilitarian functions, fashion, symbolism, religion, etc.). Each particular artefact necessarily involves all three of these components, their mutual relationships, however, is not trivial. On examples of several archaeological artefacts (fortification of ancient Roman short camp, bracelet from the Roman and the Migration period, boot, spur, wall and axe from the 9th century A.D., ring from the early Bronze Age) we tried to demonstrate some independence of the above mentioned three aspects and their specific interactions. Interpretation of the role of any particular archaeological artefact in life of past people/societies should take all of these aspects into account.

KEY WORDS archaeological anthropology; artefact; human-artefact relationship; technology; utilitarian functions; social status; symbolism; Early Bronze Age; Roman Period; Migration Period; Early Medieval Period; fortification; bracelet; ring; spur; axe

ABSTRAKT Artefakty vytvořené člověkem jsou na jedné straně kulturně univerzální, nebot představují vylepšené prostředky pro naplňování evolučně starých biologických funkcí (získávání potravy, hájení teritoria, prezentace sociálního statusu, reprodukce a organizace života sociální skupiny). Na straně druhé se kultury v jejich detailních formách velmi liší díky rozdílům v technologiích, náboženství, symbolice, módě, aj. Jedním z témat archeologické antropologie je vztah člověka a artefaktu, který lze vyjádřit trojstrannou interakcí artefaktu, člověka a účelu. Artefakt je podřízen dostupnosti (př́rodní prostředí) a vlastnostem použité suroviny, současně však bezprostředně odráží vlastnosti člověka (resp. společnosti), který ho používá (tělesné rozměry, věk, pohlaví, zdravotní stav, časové možnosti, technologickou úroveň, materiální zdroje, tradice), zároveň musí v požadované míře respektovat účel, pro který byl vyroben, resp. ke kterému se užívá (pracovní/utilitární funkce, móda, symbolika, náboženství aj.). Každý konkrétní artefakt nezbytně zahrnuje všechny tyto tři komponenty, jejich vzájemný vztah však není triviální. Na př́ikladu několika artefaktů $\mathrm{z}$ archeologických nálezů (opevnění římského krátkodobého tábora, náramek v době římské a stěhování národů, bota a ostruha, hradba a sekera v 9. století, prsten ve starší době bronzové) jsme se pokusili demonstrovat určitou autonomii uvedených tří rovin a současně jejich specifické interakce. Interpretace role každého konkrétního archeologického artefaktu v životě tehdejšího člověka/společnosti by měla zohledňovat všechny zmíněné roviny.

KLÍČOVÁ SLOVA archeologická antropologie; artefakt; vztah artefaktu a člověka; technologie; užitná funkce; sociální status; symbolika; starší doba bronzová; doba římská; doba stěhování národů; doba hradištní; opevnění; náramek; prsten; ostruha; sekera

\section{ÚVOD (Josef Unger)}

Archeologická antropologie, tak jak byla před časem definována, se zaměřuje na rekonstrukci života konkrétních lidí či malých definovaných skupin v minulosti na základě archeologických pramenů, které mají jiný charakter než prameny písemné a jejich interpretace vyžaduje jiné metody. Vychází z toho, že smyslem archeologického bádání není jen objevení 


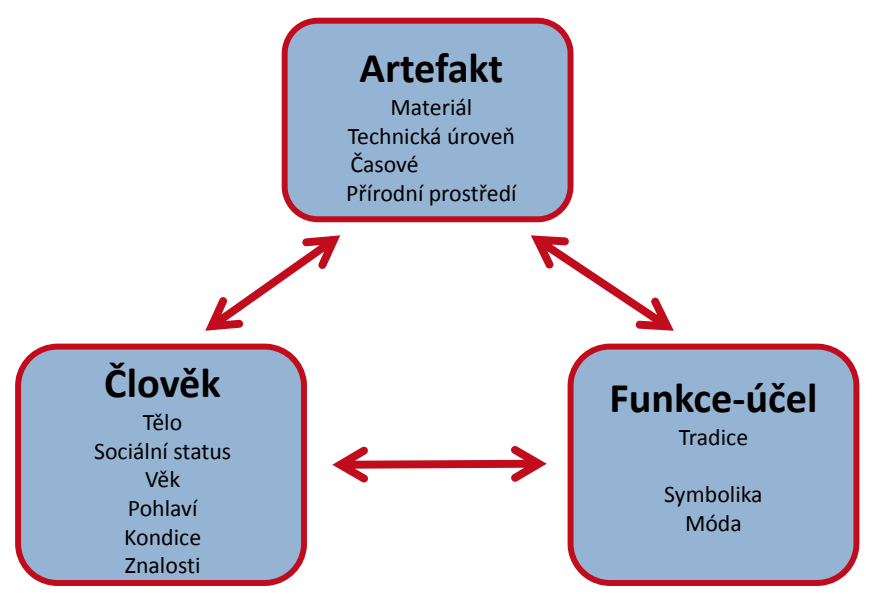

Obr. 1. Schematické vyjádření vztahu mezi člověkem, artefaktem a funkcí (účelem).

památek, jejich exkavace, deskripce a chronologické zařazení, ale rekonstrukce života konkrétních lidí v minulosti. Stejným dechem je však třeba dodat, že tato rekonstrukce musí být provedena na základě znalosti a kritické analýzy pramenů. Konkrétní naplnění tohoto badatelského směru se jevilo ve třech rovinách, přičemž jako nejspecifičtější se jeví vztah člověka a artefaktu (Unger 2005).

Vztah člověka a artefaktu řeší celá řada oborů, at’ se již jedná $\mathrm{o}$ architekturu či design. Také $\mathrm{v}$ archeologii má toto studium svoje místo, protože zatím se běžně studuje artefakt $\mathrm{v}$ archeologickém kontextu především z hlediska typologického, chronologického a někdy i symbolického, což je dáno vzděláním většiny archeologů. $\mathrm{Na}$ význam studia artefaktů $\mathrm{z}$ hlediska praktické funkce, společenského významu a symbolického smyslu poukazuje v poslední době Evžen Neústupný (2010; Kuna 2013, 415). K studiu vztahu lidského těla a artefaktu je však kromě archeologických znalostí zapotřebí i znalost anatomie, $\mathrm{v}$ některých prípadech i anatomie vývojové, čímž dochází k propojení fyzické (biologické) antropologie a archeologie.

Vztah člověka a artefaktu lze vyjádřit trojúhelníkem zobrazujícím artefakt, člověka a účel (obr. 1). Všechny tři komponenty jsou důležité a je možno je blíže charakterizovat. U artefaktu je nutno zohlednit materiál a technickou úroveň. Do této komponenty lze zahrnout i časové možnosti a př́írodní prostředí ovlivňující dostupnost materiálu. Další komponentou je účel nebo funkce artefaktu ve vztahu k člověku. Zde hrají svoji úlohu tradice, náboženství, móda a symbolika. U člověka je třeba zohlednit stavbu lidského těla, věk, pohlaví, kondici, zdravotní stav, úroveň znalostí a sociální status. Samozřejmě ne vždy je možno využít všechny komponenty, ale schéma naznačuje jejich důležitost. Následující př́ípadové studie ukazují na možnosti a některé dosažené výsledky, které jsou stručně přiblíženy v jednotlivých kapitolách tohoto článku.

\section{POKUSNÉ OVĚŘENÍ BUDOVÁNÍ OPEVNĚNÍ ŘÍMSKÉHO KRÁTKODOBÉHO TÁBORA (Martin Mazáč)}

Ř́mská moc se v době svého největšího rozmachu rozprostírala kolem celého Středozemního moře, od Británie k Černému moři, od Dunaje $\mathrm{k}$ pramenům Nilu. Tato moc mohla být udržována a dále rozšiřována jen díky výkonné vnitřní správě, diplomacii a v neposlední řadě disciplíně, odvaze a vysoké kvalitě rrímského vojska. Jednou z mnoha věcí, ve kterých Rímané vynikali, byly inženýrské a stavební práce, at' už se týkaly mostů, akvaduktů, obléhacích či obranných pevností nebo táborů. Dlouhodobé tábory se pak stávaly téměř samostatnými městy s vlastní správou, lázněmi, obchody, stájemi a podobně a některé $\mathrm{z}$ nich se pak ve skutečná města opravdu přeměnily (Conolly 1992, 38).

Krátkodobé, neboli pochodové, tábory se těm dlouhodobějším podobaly svou strukturou a organizací, a jak jejich název napovídá, byly budovány za účelem krátkodobého pobytu na jednom místě. Často se jednalo o pobyt pouze na jednu noc či maximálně na několik dní. Avšak i takovéto tábory bývaly poměrně dobře opevněné. Kolem celého tábora byl vyko-

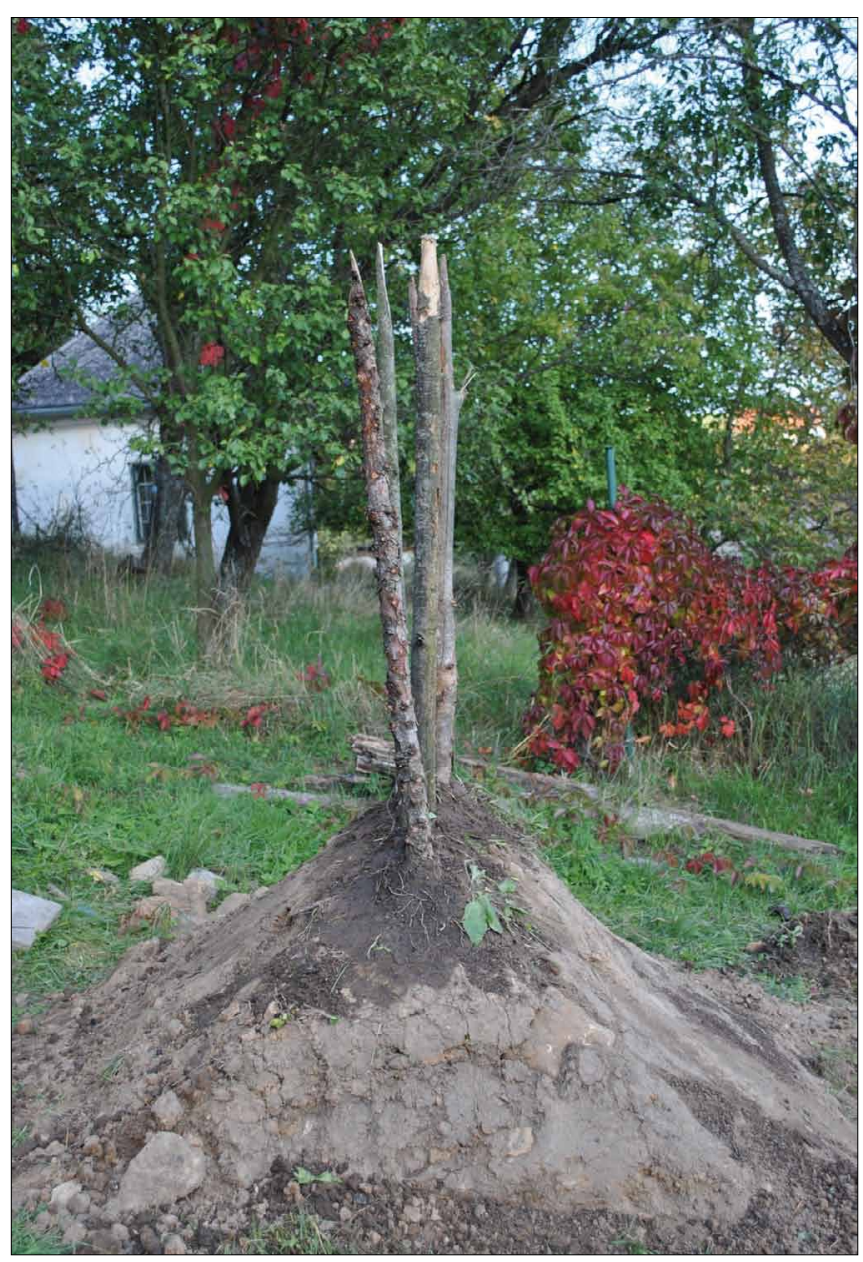

Obr. 2. Průřez náspem s dřevěnými kolíky umístěnými na hřebeni. 


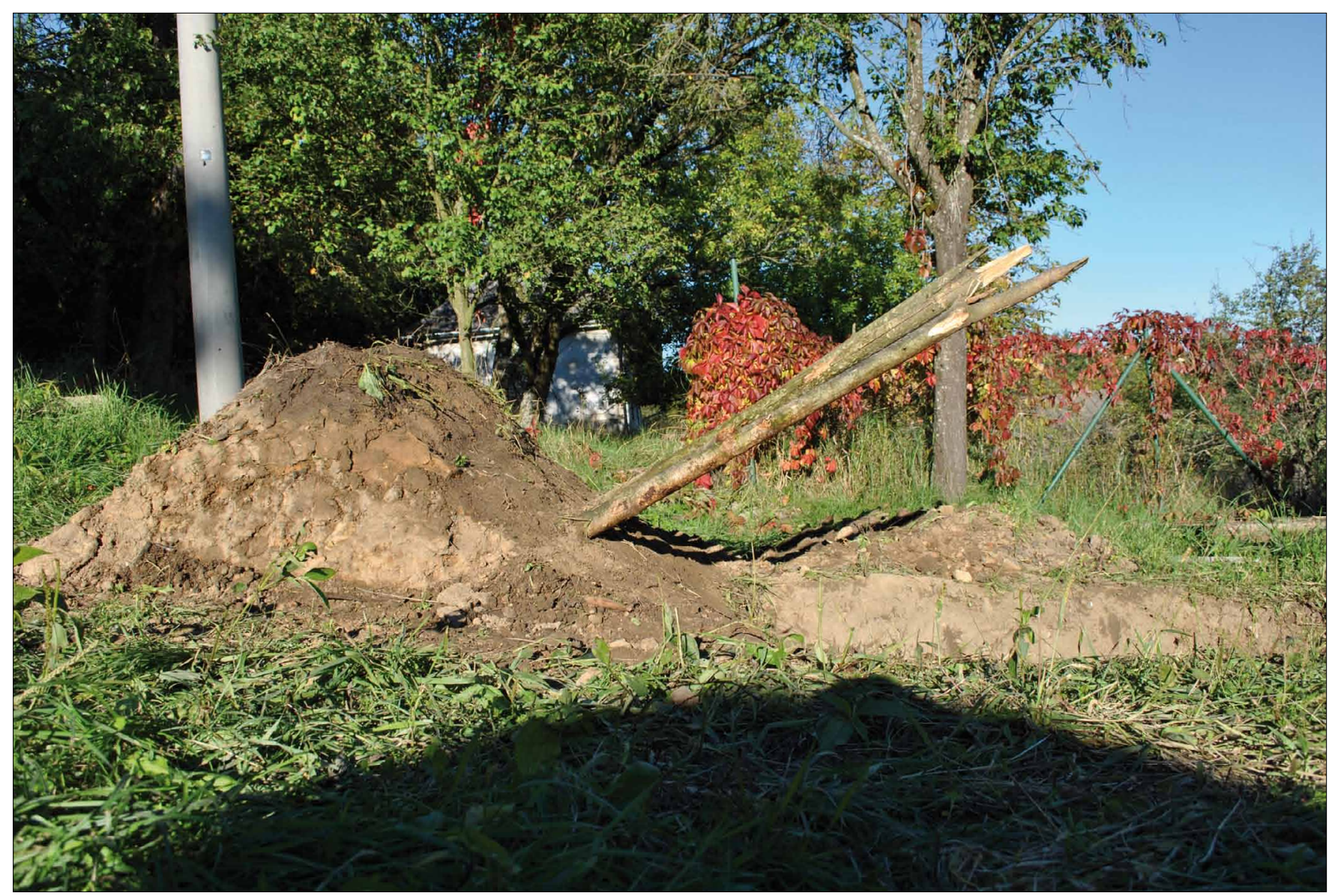

Obr. 3. Průřez náspem s dřevěnými kolíky umístěnými na úpatí náspu.

pán příkop a navršen násep, na jehož vrcholku byla umístěna palisáda ze speciálně upravených kůlů zvaných pila muralia (Conolly 1992, 12; Vegetius 1977, 433, 476).

Flavius Vegetius Renatus se ve svých spisech zmiňuje o několika možných velikostech příkopu. Od nejjednoduššího, kdy se pouze vykopaly drny a navršily do výšky asi tří stop (asi 0,9 $\mathrm{m})$, až po délku př́íkopu dvanáct stop, což je 3,6 m a hloubku devět stop, což představuje $2,7 \mathrm{~m}$ (Vegetius1977, 433). Tomu i většinou odpovídají profily nalezených příkopů pochodových táborů, u nichž se podle archeologického zkoumání pohybuje hloubka od 0,9 až k téměř $4 \mathrm{~m}$ a šírka od 0,5 až $\mathrm{k} 7,5 \mathrm{~m}$ (Droberjar 2002, 286). Převážně je však hloubka kolem $1,5 \mathrm{~m}$ a šírka kolem $2,5 \mathrm{~m}$. O velikosti náspů se bohužel mnoho neví především díky jejich destrukci, at' už časem nebo násilím, a také písemné prameny jsou na tyto informace skoupé. Vegetius popisuje přesnější výšku náspu pouze v jednom případě, a to čtyři stopy, což je 1,2 m (Vegetius 1977, 433) u celkem velkého př́kopu.

Z hlediska ověření možností jsem pracoval s imaginárním táborem čtvercového půdorysu o velikosti jedné strany $700 \mathrm{~m}$, který by byl dozajista dostačující pro celou legii, možná dokonce i pro více jednotek. Obvod celého tohoto tábora by byl $2800 \mathrm{~m}$. Pokud bychom počítali, že v legii se nachází kolem 6000 mužů, tak se dá odvodit, že pokud by na jednoho muže ke kopání vycházel úsek jeden metr široký, tak k opevňovacím pracím by nebyla potřeba ani polovina mužů legie.

Počítal jsem $s$ tím, že i pochodový tábor bylo nutné řádně opevnit dostatečným náspem s kůlovou palisádou a že tato palisáda, aby byla účinná, měla být tvořena $\mathrm{z}$ kůlů dlouhých maximálně $3 \mathrm{~m}$ o průměru $15 \mathrm{~cm}$. Tato představa se ukázala jako nereálná, protože takové kůly by s sebou legionáři nosit nemohli (a pokud ano, bylo by jich zoufale málo). Nemohli je ani získávat na místě, protože zajištění dostatečného množství by bylo logisticky náročné (bylo by potřeba pokácet a rozřezat alespoň tři tisíce stromů) na tak krátkodobou stavbu, když se předpokládá, že celý tábor musel být opevněn asi za dvě, maximálně tři hodiny a ráno rozebrán a opuštěn. Opustil jsem tedy tuto hypotézu a uvažoval o použití kůlu dlouhého $1,5 \mathrm{~m}$, který si sami legionáři nosili či vozili na soumarech (Conolly 1992, 12, 27). Dalším východiskem úvah bylo, že násep, aby byl funkční, musel být dostatečně vysoký a navíc na vnitřní straně mít dostatečně prostornou rampu pro pohyb obránců. Na takovou stavbu by však bylo potřeba mnohem větší množství hlíny, než by se dalo získat $\mathrm{z}$ př́ikopu, které popisuje Vegetius $(1977,433,476)$.

Pokusil jsem se ověřit čas potřebný $\mathrm{k}$ budování a obranyschopnost tohoto zařízení pro což jsem vybral jeden z modelových typů prŕkopu od Vegetia (Vegetius1977, 476) s hloubkou 
tři stopy $(0,9 \mathrm{~m})$ a délkou pět stop $(1,5 \mathrm{~m})$ o kterém říká, že byl tím minimem, který museli legionáři vykopat, pokud nebylo možné vytvořit opevnění pouze z drnů (Vegetius 1977, 476). Vybral jsem si jej také $\mathrm{z}$ důvodu celkově menší náročnosti.

Pokus jsem prováděl na místě v mírném svahu nad terénní vlnou. Takováto lokace nebyla pro římské tábory ničím neobvyklým. Plánoval jsem vybudovat pouze část opevnění, velké tak, aby připadlo jednomu legionáři, což znamená asi metr na délku příkopu (šírka $1,5 \mathrm{~m}$ a hloubka $0,9 \mathrm{~m}$ ). Použil jsem obyčejné zemědělské nástroje - rýč a krátkou lopatu, kterými jsem nahradil původní ŕímské nástroje (Římané používali velmi podobné). Krumpáč jsem $\mathrm{k}$ dispozici neměl. Kopal jsem sám a za dvě a čtvrt hodiny jsem dokázal vyhloubit příkop 0,7 m hluboký, 1,6 m široký a 1,05 m dlouhý a navršit násep vysoký $0,6 \mathrm{~m}$, široký $1,45 \mathrm{~m}$ a dlouhý $1,05 \mathrm{~m}$. Hloubka byla menši než předpokládaná díky jílovito-kamenitému podloží, na které jsem v hloubce asi padesáti centimetrů narazil. Násep jsem vršil a udupával tím způsobem, aby byl co nejvyšší $s$ co nejmenší základnou. Násep měl na průřezu tvar rovnoramenného trojúhelníka (obr. 2). Druhá část pokusu měla zjistit obranyschopnost takového opevnění. Zde jsem se inspiroval kresebnou rekonstrukcí Bernharda Rudnicka (Rudnick 2012, 230). Pro věrnější rekonstrukci jsem na vrchol náspu zakopal dřevěné kůly, které byly náhradou za pila muralia legionářů. Kůly měly délku $1,5 \mathrm{~m}$, průřez kolem pěti centimetrů a zahloubeny byly $0,4 \mathrm{~m}$ do země. Rozestup mezi jednotlivými kolíky byl deset až patnáct centimetrů, což se ukázalo jako dostatečné, palisáda tedy nemusela vytvářet souvislou stěnu. Hloubku zakopání kolíků jsem vypočítal podle Z. Webera (Weber 1969, 219-222).

Výsledkem bylo zjištění, že takovéto opevnění s palisádou bylo možné lehce ubránit proti frontálnímu útoku, protože útočník nejprve musel prrekonat př́kop (skokem nebo proběhnutím) a poté navíc vyšplhat na násep, kde však už byl $\mathrm{v}$ dosahu zbraní obránců (především kopí a oštěpů). Navíc musel ještě na hřebeni překonat palisádu, která byla špatně dosažitelná zbraněmi, a také bylo obtížné ji vyvrátit pouhým nárazem. Ona hloubka čtyřiceti centimetrů, do které byly kůly ukotveny, se prokázala jako dostatečná.

Když však byly kủly umístěny na úpatí náspu kolmo proti nepříteli (obr. 3), jak se někdy uvádí (Rudnick 2012, 230), byla palisáda lehce zničitelná těžšími zbraněmi (sekerami, kladivy) a útočník byl navíc z dosahu zbraní obránců. Stále však zůstával problém vyšplhat na násep bráněný nepřítelem.

Výsledky tohoto pokusu, který nemá charakter vědeckého ex-

\begin{tabular}{|c|c|c|c|}
\hline Lokalita & Hmotnost (g) & Počet solidů & Vnitřní rozměry (cm) \\
\hline 1 Tournai & 300,00 & 67 & $6,0 \times 4,6$ \\
\hline 2 Apahida & 230,20 & 51 & $7,5 \times 5,6$ \\
\hline 3 Blučina & 226,70 & 50 & $6,0 \times 5,5$ \\
\hline 4 Pouan & 171,00 & 38 & $6,5 \times 5,2$ \\
\hline 5 Střední Čechy & 160,68 & 36 & $6,3 \times 5,7$ \\
\hline
\end{tabular}

Obr. 4. Rozměry a hmotnosti náramků dle Wernera 1980. Převzato z Droberjar 2001, str. 522 . perimentu, potvrdily, že opevnění pochodového římského tábora mohlo být hotové zhruba za dvě hodiny a navíc nemuseli být využiti ani všichni muži legie, protože jich stačila pouhá polovina. Potvrdilo se, že i tak malý a nenáročný př́íkop a násep jsou poměrně velkou překážkou ke zdolání.

\section{ČLOVĚK A NÁRAMEK V DOBĚ ŘÍMSKÉ A STĚHOVÁNÍ NÁRODŮ (Milada Hylmarová)}

Horní končetina má u člověka odlišnou funkci než u ostatních savců. Z oporné končetiny, která je používána při lokomoci těla, se v průběhu evoluce a s rozvojem bipedie stal komunikační orgán, který umocňuje komunikaci a gestikulaci. Je pro ni charakteristický velký rozsah pohybu, který je dán především volností $\mathrm{v}$ ramenním kloubu. Velmi specifická je pak stavba samotné ruky, kde došlo k výrazné diferenciaci svalů i kostí, a vytvořila se opozice palce. Tyto změny umožňují člověku přesnou manipulaci s předměty a jemnou motorickou činnost, ale zároveň vytvářejí dostatečnou sílu pro pevný úchop předmětu.

Pro zkoumání vztahu horní končetiny člověka a náramku je důležitá představa o kostěném podkladu a mocnosti svalů

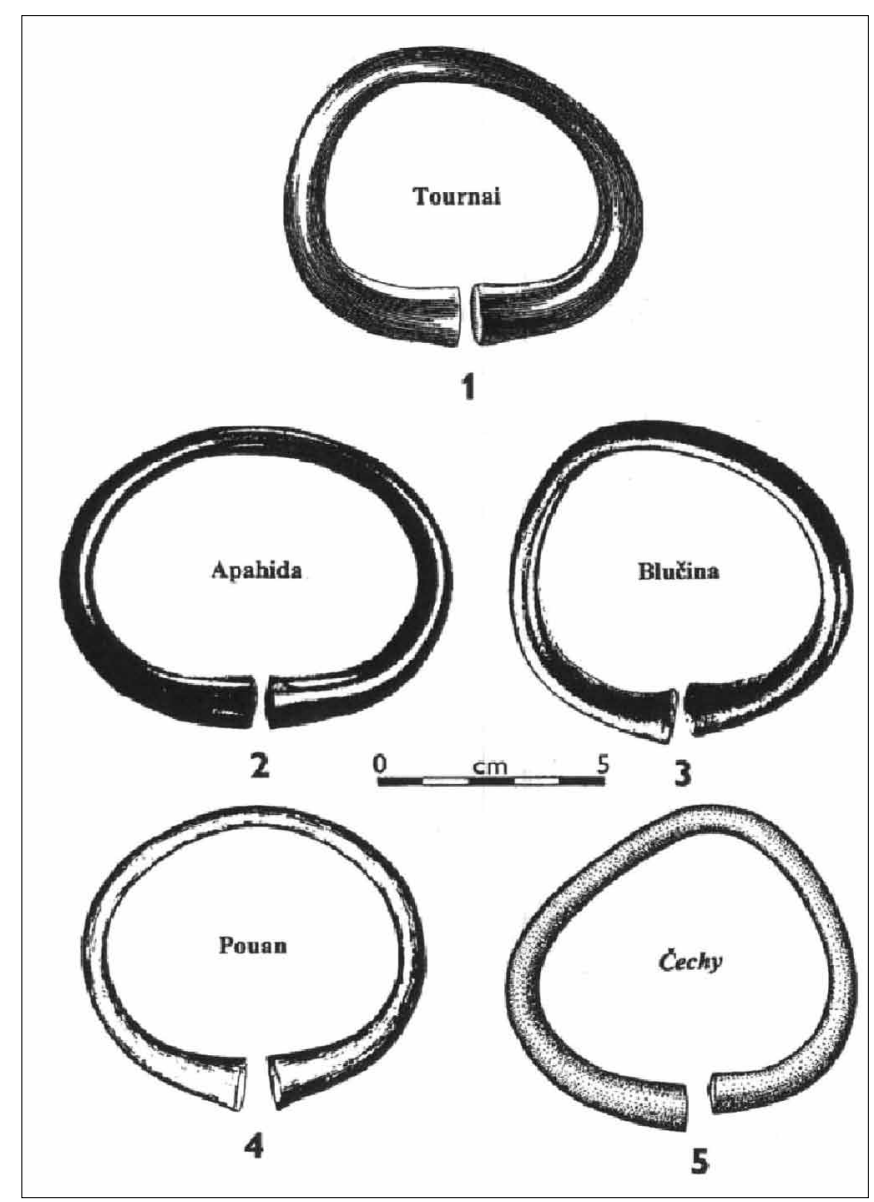

Obr. 5. Přehled masivních zlatých náramků na evropských lokalitách. Převzato z Droberjar 2001, str. 520. 


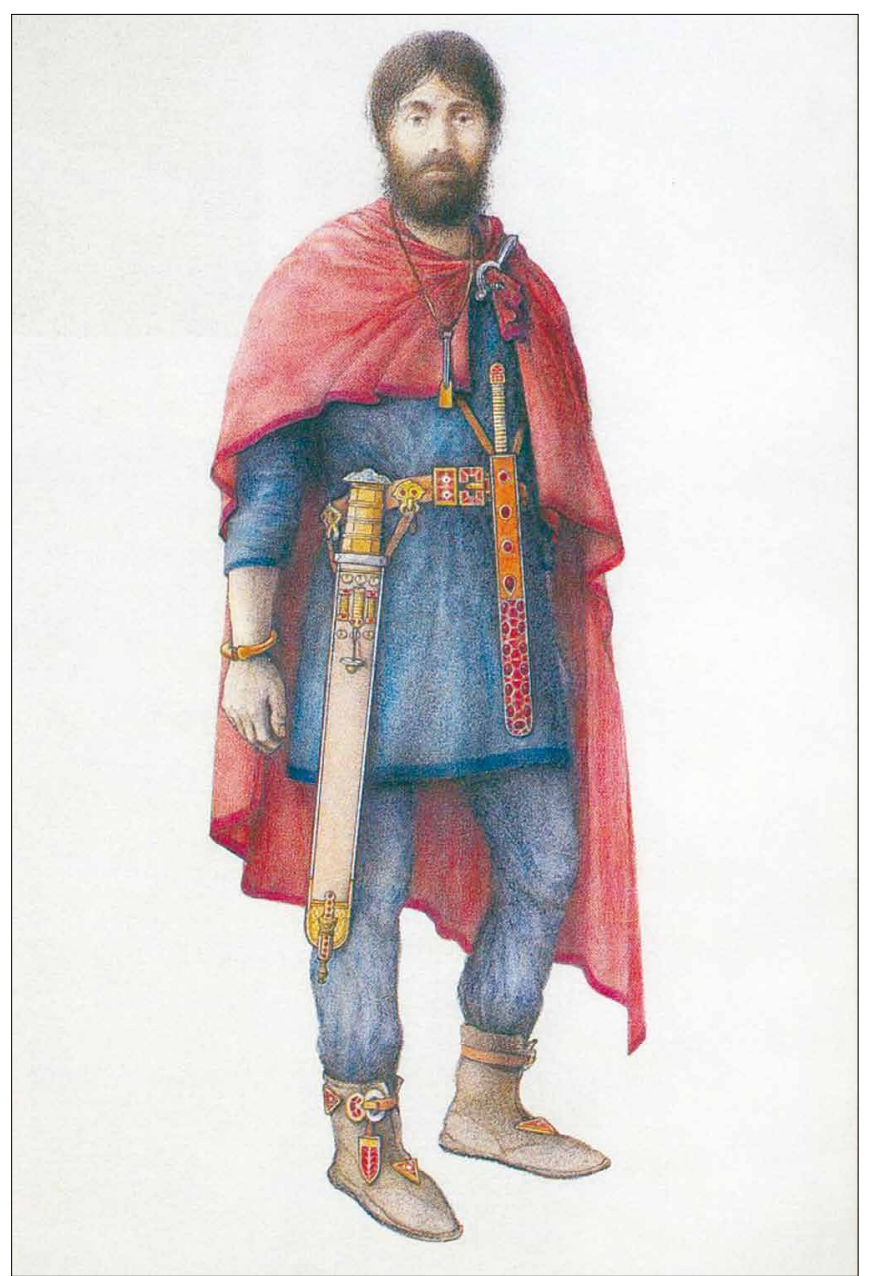

Obr. 6. Rekonstrukce podoby germánského panovníka z hrobu z Blučiny podle Pavla Dvorského. Převzato z http://www.templ.net/cesky/vyroba-mec_z_bluciny.php

v jednotlivých částech končetiny. Paže je rovnoměrně pokryta svaly probíhajícími od ramene až na proximální části předloketních kostí. Předloktí je charakterizováno průběhem flexorů a extenzorů ruky od distálního konce humeru až do dlaně. Tyto svaly mají výrazné svalové břiško a dlouhou úponovou šlachu. Tato disproporce vytváří výraznou svalovou strukturu v proximální části předloktí, na distálním konci pak procházejí pouze úponové šlachy a profil předloktí se tak výrazně zužuje. Pro navlečení náramku je důležitý největší rozměr dlaně $\mathrm{v}$ poloze metakarpofalangeálních kloubů, navlečení může omezovat i vyvinuté svalstvo malíkového a palcového valu dlaně. V této oblasti je nutné náramek přes dlaň přetáhnout. Náramek mohl být nošen volně na předloktí, nebo jako nápažník nad loktem, tento způsob nošení ale není v těchto obdobích běžný, a jak se ukázalo, ani náramky nejsou dostatečně velké, aby mohly být takto nošeny.

Náramek byl v době římské a stěhování národů běžně používaným artefaktem a dosahoval velké tvarové rozmanitosti. Jako materiál byly většinou používané drahé kovy (bronz, zlato, stříbro). Náramky jsou nejčastěji nalézány v ženských hro- bech. Zajímavým prvkem jsou masivní zlaté náramky, které jsou nalézány $\mathrm{v}$ mužských hrobech germánských králů. Tyto náramky byly vyráběny z římských solidů, jimž odpovídají složením a hmotností (Droberjar 2001, 523-524). Na průřezu jde o kulatou tyčinku proměnlivého průměru $(5-10 \mathrm{~mm}) \mathrm{s}$ rozšířenými konci. Zajímavé je, že na všech evropských lokalitách jsou náramky tvarově i rozměrově velmi podobné (obr. 4,5 ). To naznačuje, že byly používány k podobnému účelu, tedy jako odznak moci germánského panovníka, jak to známe i z dobových vyobrazení na prstenech a mincích (Droberjar 2001, 519). Hlavní otázkou bylo, jak byly tyto zlaté náramky nasazovány na ruku? Je vůbec možné náramek pohodlně přetáhnout přes dlaň? Pro toto zkoumání byly získány obvodové míry horních končetin 112 lidí dnešní populace, šlo o muže i ženy různého věku a tělesných proporcí. Bylo zjištěno, že masivní zlatý náramek může být volně zavěšen na předloktí dospělého muže, není ale možné jej plynule přetáhnout přes dlaň. Vhodná řešení nasazení náramku se nakonec nabízejí dvě. Náramek mohl být nasazen na ruku dítěti do věku 12 let, potomkovi panovníka a dědici titulu. Asi do tohoto věku (s ohledem na individualitu každého člověka) mohl být náramek pohodlně přetažen přes dlaň na předloktí. Druhou možností bylo nasazení náramku dospělému jedinci při korunovaci, převzetí úřadu panovníka. Náramek není uzavřený a zlato je měkký kov, je tedy možné náramek roztáhnout, nasadit na předloktí a znovu uzavř́t. K tomuto úkonu ale nemohlo docházet často, protože materiál by se $\mathrm{v}$ místě ohýbání unavil a mohl by prasknout, mohlo tedy jít o součást rituálu, slavnosti, kdy byl panovník uveden do funkce. $\mathrm{V}$ obou případech je náramek použit jako symbol panovnické moci a povinností panovníka jako hlavy daného germánského kmene (obr. 6).

\section{ČLOVĚK - BOTA - OSTRUHA V 9. STOLETÍ (Josef Unger)}

Objev hrobu s ostruhami na středohradištním pohřebišti v Divákách byl podnětem pro experimentální ověření vztahu chodidla, obuvi a ostruhy se zaměřením na rekonstrukci upínání. Experiment proběhl tak, že po konzervaci ostruhy s nákončím a průvlečkou Patrick Bárta zhotovil kovářskou technikou kopii ostruhy s př́slušenstvím (přezka a průvlečka). $\mathrm{Na}$ základě důkladného studia obuvi Václav Gřešák zhotovil jednu botu a příslušné řmínky $\mathrm{k}$ ostruze. Botu přizpůsobil na svoje chodidlo Zdeněk Tvrdý. Po spojení řemínků s ploténkami ostruhy, které provedl Patrick Bárta tak, že na konec jednoho řemínku byla připojena přezka s průvlečkou a konec druhého řemínku byl ponechán volný (obr. 7), byl hledán nejvhodnější způsob připnutí ostruhy přímo k botě. Jako nejvhodnější se ukázal způsob, kdy řemínky vedoucí z plotének se nejdříve překřiží na přední straně boty nad nártem, potom se překříží na spodní straně obuvi a nakonec sepnou na vnější straně boty (obr. 8). Ostruha dobře drží a přezka s průvlečkou na vnější straně nedře při jízdě koně. Přesto se jedná o způsob, který v dalším vývoji ostruh neměl pokračování a byl nahrazen jednodušším způsobem, kdy z konce ramen ostruhy 


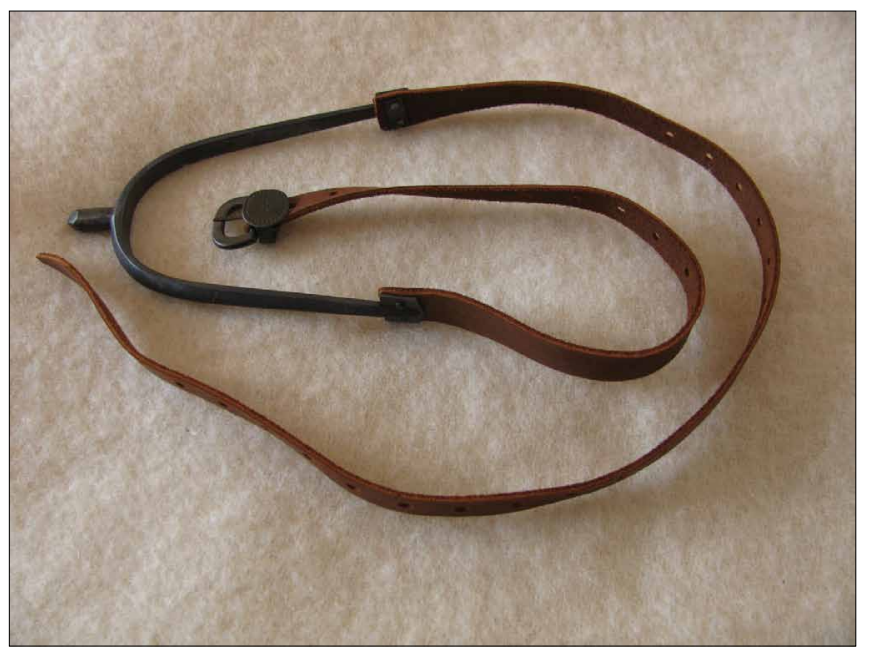

Obr. 7. Rekonstrukce ostruhy a upínacích řemínků.

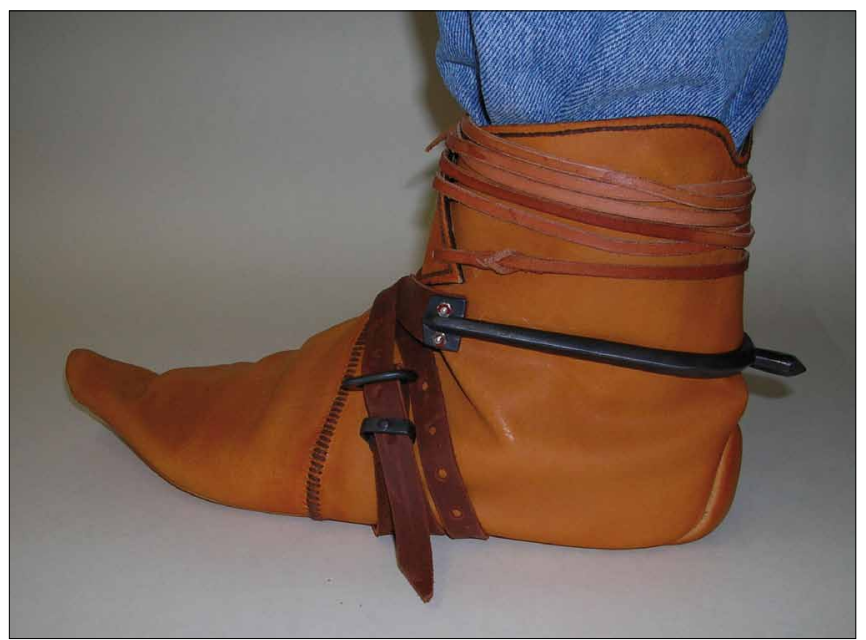

Obr. 8. Rekonstrukce připnutí ostruhy k botě.

vycházel jeden řemínek pod botu a druhý řemínek s přezkou na zapnutí nad nártem (Unger 2010).

\section{ČLOVĚK A HRADBA V 9. STOLETÍ (Josef Unger)}

Problém rekonstrukce předvelkomoravských a velkomoravských hradeb, u nichž díky archeologickým výzkumům známe šiŕku i způsob konstrukce, ale neznáme podobu temene hradby, lze řešit i $z$ hlediska vztahu člověka a artefaktu. $Z$ tohoto důvodu jsou důležité některé míry lidského těla (obr. 9). Především se jedná o výšku postavy dospělého člověka. Hradby by měly být konstruovány tak aby za nimi našli kryt celého těla nejen průměrně, ale i nadprůměrně vysocí muži. Další důležitou mírou byla výška po prsa, protože při krytí spodní části těla zůstávají horní končetiny funkční pro obranu. Výška po pás byla důležitá kvůli předklonu, který byl zapotřebí pro kontrolu prostoru před hradbou. Kvůli předklonu, při němž

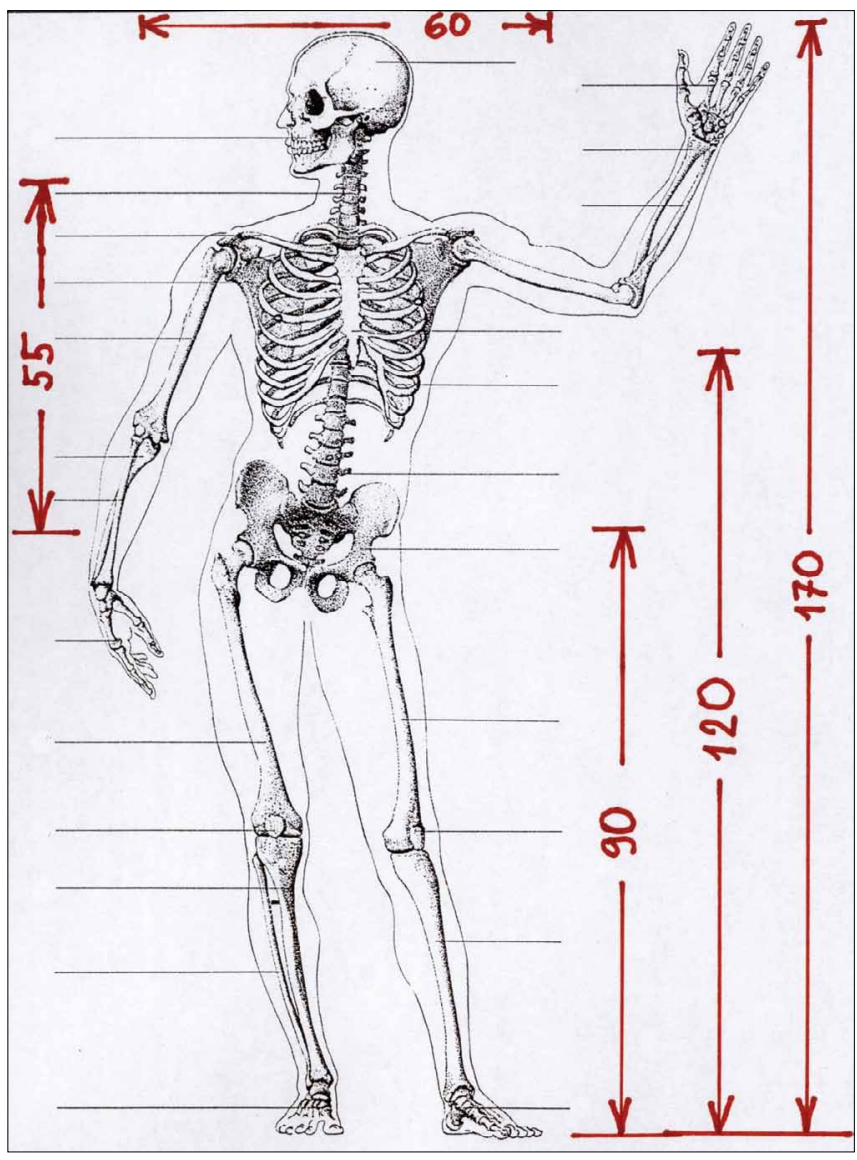

Obr. 9. Rozměry lidského těla důležité z hlediska rekonstrukce temena hradby.

lze vizuálně i hlasově kontrolovat prostor před hradbou, je důležitá délka mezi pasem a bradou. $Z$ tohoto rozměru lze odvodit i maximální šířku části hradby, přes kterou bylo třeba se naklánět. Šírka ramen naznačuje minimální akční prostor pro obranu.

$\mathrm{S}$ přihlédnutím $\mathrm{k}$ výše uvedeným antropometrickým údajům lze uvažovat o některých fortifikačních prvcích na temeni velkomoravských hradeb. Na dřevohlinitém tělese širokém 4 až $6 \mathrm{~m}$ s čelní kamennou zdí a zadní dřevěnou stěnou by bylo vhodné vybudovat hustou palisádu ze svisle zapuštěných kůlů a tuto hluboko zapustit do tělesa hradby. Čelní kamenná zed' by se měla směrem nahoru zúžit až na $30 \mathrm{~cm}$ (1 stopa), což by umožňovalo kontrolu i úpatí hradby na vnější straně. Palisádu na temeni hradby by bylo dobré vybudovat $\mathrm{v}$ podobě cimbuř́i se stínkami o výšce $180 \mathrm{~cm}$ (6 stop) a délce $120 \mathrm{~cm}$ (4 stopy) a prolukami o výšce $90 \mathrm{~cm}$ (3 stopy) a minimální délce $60 \mathrm{~cm}$ (2 stopy). Výška proluky umožňuje kontrolu prostoru na vnější straně hradby a také střelbu $\mathrm{z}$ luku. Za stínkou se mohou ukrýt dva obránci a to i nadprůměrně vysocí (obr. 10). V př́padě, že by se považovalo za žádoucí, aby hradbu $\mathrm{v}$ proluce byli schopni současně bránit dva obránci, pak by bylo třeba proluku rozšířit minimálně na čtyři stopy. Palisádu ve stínkách ani v prolukách není nutno na svrchní straně zahrocovat, protože v prolukách by to znemožňovalo naklánění přes hradbu. Koruna tělesa hradby by měla být rovná tak aby 


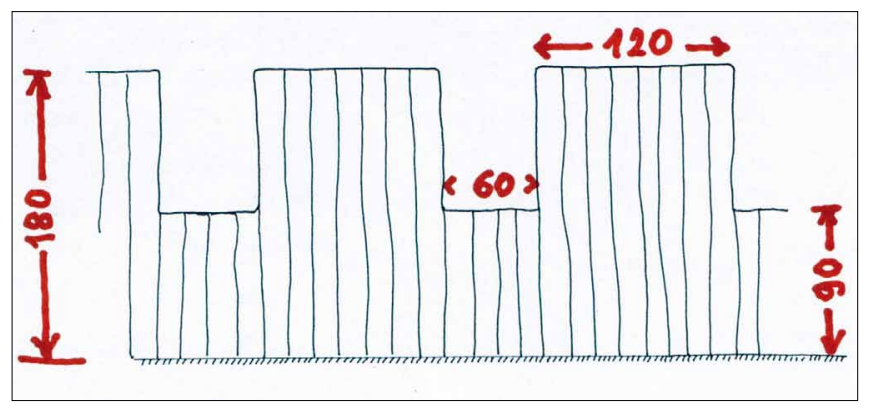

Obr. 10. Rekonstrukce palisádového cimbuří na temeni hradby.

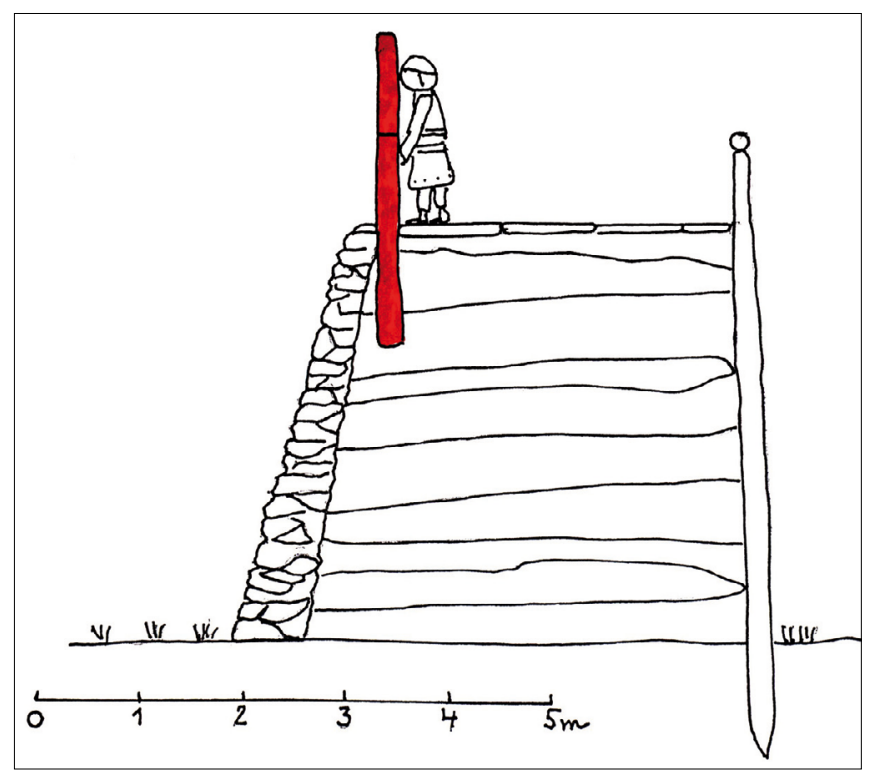

Obr. 11. Rekonstrukce hradby.

umožňovala bezpečný pohyb většího množství obránců, což se považuje za hlavní účel šírky hradeb, které nebylo možné tehdy běžnými prostředky prolomit (obr. 11). Povrch na ko- runě hradby bylo dobré upravit tak aby i při dešti umožňoval obráncům dobrý pohyb. Vhodné by bylo i mírné spádování kvůli odtoku vody. Zastřešení celého ochozu by bylo žádoucí, ale neuvažuje se o něm. Po dvaceti krocích by měl být umístěn vstup na hradbu z vnitřní strany kvůli možnosti rychlého přemístování obránců (Unger 2008).

\section{ČLOVĚK A SEKERA V 9. STOLETÍ (Miroslav Šenkýř)}

Vztah člověka a sekery může být různorodý. Mưže být využita jako symbol postavení či skupiny. Vždy je však za takovým symbolem nějaké praktické využití sekery. Převážně se tedy jedná o pracovní či bojový nástroj, což se ve valné většině prŕípadů prolíná. Výjimkou jsou merovejské francisky, které mají čistě bojovou funkci. Jiným př́íkladem specializace těchto nástrojů jsou moravské sekery z 9. století.

Moravská bradatice je tvarově charakteristická, nemá obdoby v západních ani severských zemích. Hlavními rozdíly, oproti jiným druhům seker jsou krátká, různě tvarovaná brada, ostny v okolí násadního otvoru sekery a týl prodloužený v tvarovanou patku. Může být i různá šírka těla sekery či tvar násadního otvoru. Těchto atributů lze využít k typologii, kterou rozpracovala celá řada autorů (Dostál 1966, 70-72, Ruttkay 1976, Abb. 42), nicméně typologická rozdělení nijak nepřispívají $\mathrm{k}$ pochopení funkce. Byla tedy vyrobena replika moravské bradatice s ostny, jejíž předlohou byly nálezy z Mikulčic. Sekeru, která by se dala zařadit do typu IA z první poloviny 9 . století, zhotovil Patrick Bárta (obr. 12).

Toporo repliky, které zhotovil autor (M.Š.) z dubového dřeva, , má délku $81 \mathrm{~cm}$, přičemž průřez je oválný s délkou $3 \mathrm{~cm}$ a šírkou $2,5 \mathrm{~cm}$ (obr. 13). Jako předloha sloužily sekery i s topory z Mikulčic (Poláček - Marek - Skopal 2000, Abb. 2227). Dưraz byl kladen hlavně na celkovou délku, pohybující se v rozmezí $55-90 \mathrm{~cm}$, a také na opracování dřeva, to je ztenčení

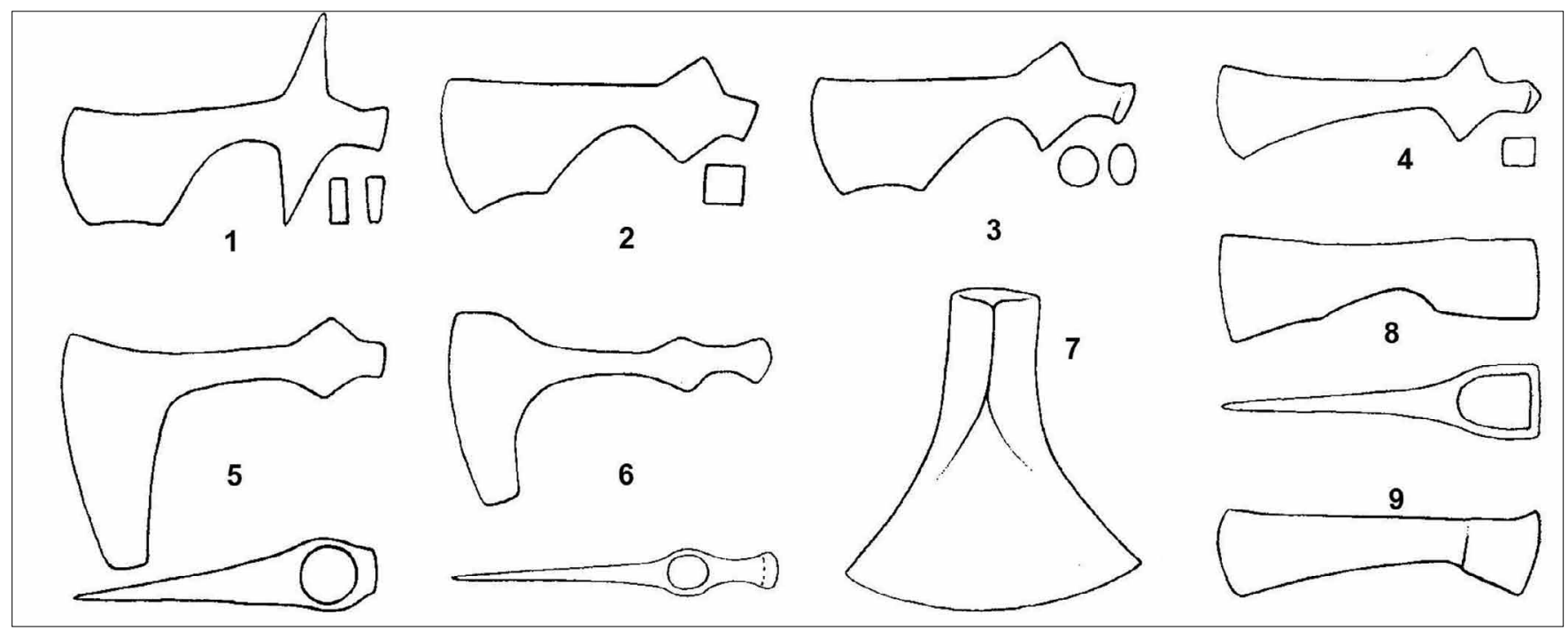

Obr. 12. Typologické rozdělení velkomoravských seker (pramen Dostál 1966, 69). 


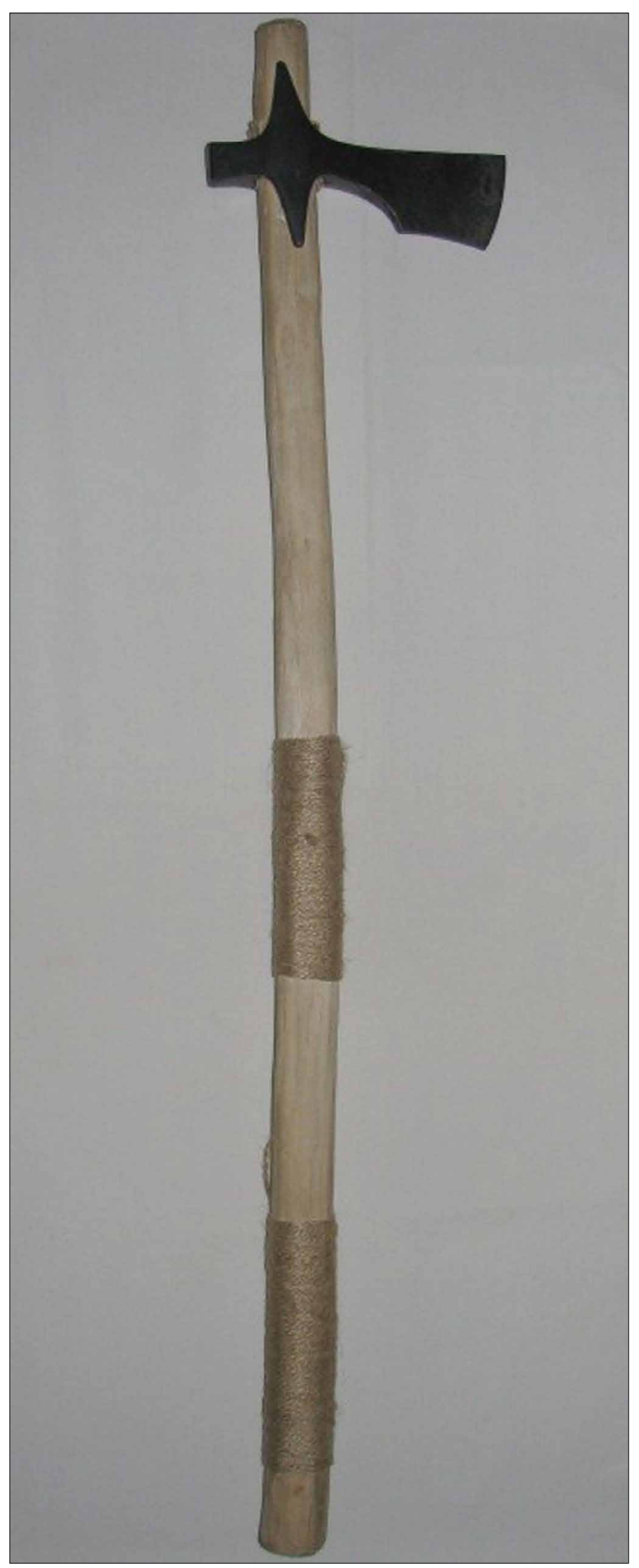

Obr. 13. Replika moravské bradatice s ostny typ IA.

na vhodnou tlouštku pro lepší úchop a manipulaci se sekerou. Ztenčení má za následek i snížení hmotnosti celého nástro-

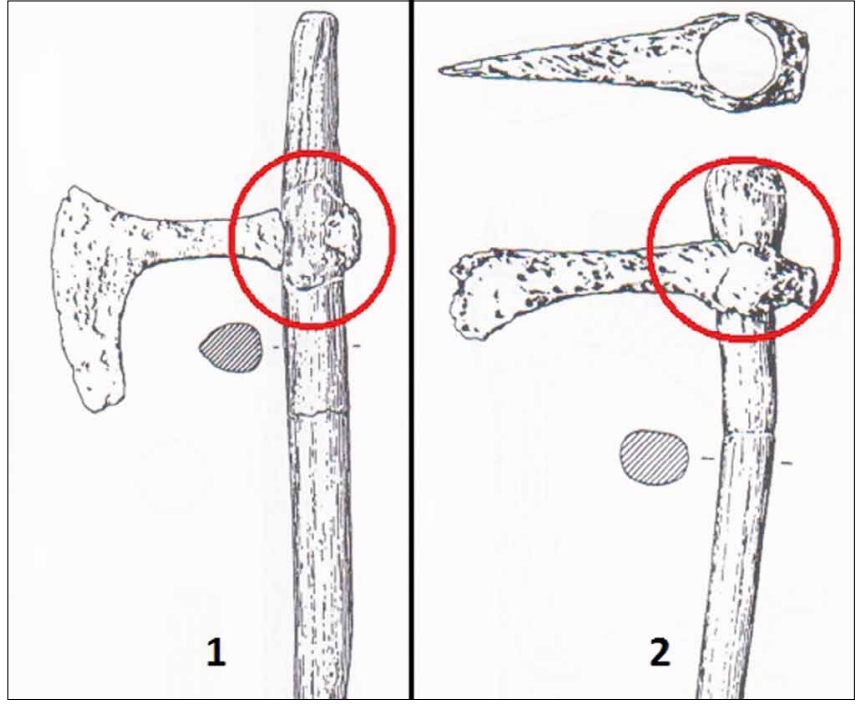

Obr. 14. Rozšíření topora nad a pod násadním otvorem sekery (pramen Poláček - Marek - Skopal 2000, Abb. 23:8, 27:1).

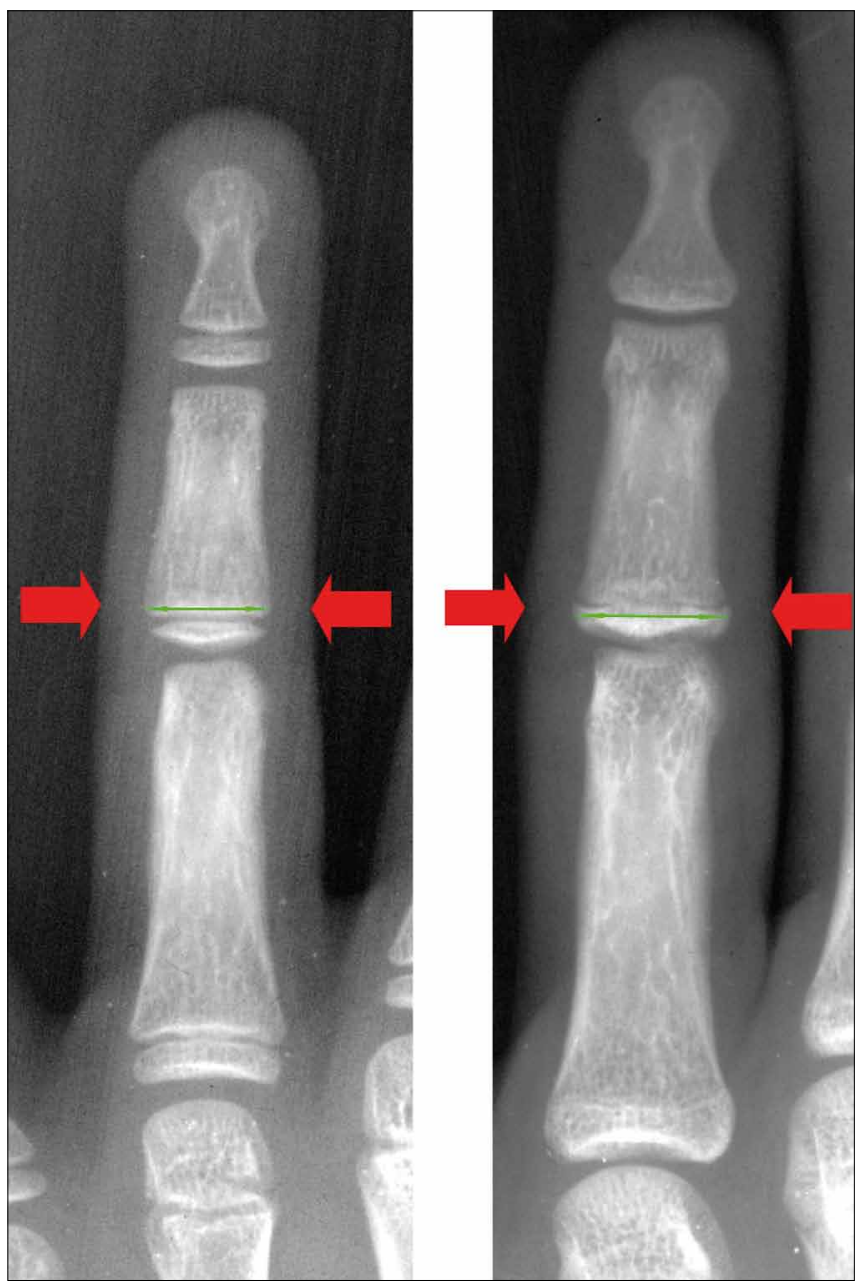

Obr. 15. Klíčové místo pro navlečení prstenu na proximální článek u tř́ičlánkového prstu ruky - základna prostředního článku; vlevo je čtvrtý prst levé ruky u nedospělého muže ve věku 10 let, vpravo je tentýž prst téhož muže ve věku 14 let - patrná je změna jak v celkové velikosti prstu, tak v relativní šírce epifýzy klíčové základy prostředního článku. 
je. Z nálezů z Mikulčic je zřejmé (Poláček - Marek - Skopal 2000, 199), že nejčastěji bylo vybíráno nejčastěji dřevo javorové (Acer sp.), méně jasanové (Fraxinus sp.) a dubové (Quercus sp.). Za výběrem těchto druhů dřevin mohly stát jejich dobré fyzikální vlastnosti, ale i jejich dostupnost a rozšíření. U nálezů z Mikulčic si lze všimnout rozdílné šířky topora u násadního otvoru sekery (Poláček - Marek - Skopal 2000, Abb. 22-27). Některé jsou pravděpodobně prrírodního původu a zbytek vznikl během opracování topora. Rozšiření mohlo mít význam jako prevence uvolňování sekery během vysušování. Zároveň lze z této skutečnosti určit i směr nasazení sekery. Pokud se rozšíření vyskytuje pod násadním otvorem sekery (obr. 14), tak je způsob nasazení klasický, tj. shodný $\mathrm{s}$ dnešními sekerami. Pokud se však rozšíření vyskytuje nad násadním otvorem sekery (obr. 14), sekera se nasazovala přes celou délku topora stejným způsobem jako krumpáč.

Důležitá je i stavba sekery jako celku. Zajímavým znakem je zešikmené nasazení topora. Možných vysvětlení tohoto jevu může být více, ovšem nepravděpodobnější je, že se sekera díky vzniklému ostrému úhlu mezi ostřím a toporem ztotožní s kruhovou drahou rozmachu a při dopadu dolehne celým břitem. Tím se zvýší její pádnost a společně s malou délkou břitu i průraznost. Zešikmení, společně s vykrojeným tělem, mohlo sloužit také jako pomůcka ke stržení nepřítelova štítu. $\mathrm{Z}$ celkového hlediska by se tedy moravské sekery zařadily do bojových nástrojů, i když nelze vyloučit jejich použití jako pracovních nástrojů.

\section{ČLOVĚK A PRSTEN VE STARŠÍ DOBĚ BRONZOVÉ (Miroslav Králik)}

Prsten je nejčastěji kroužek (jednoduchý kroužek nebo komplikovanější útvar s více či méně kruhovitým otvorem), užívaný k navlečení na prst ruky (někdy i nohy). Prsten je na ruce člověka nošen nejčastěji na proximálním článku některého tříčlánkového prstu (2. - 5. prst), méně často na palci. Asi nejvíce je nošen na 4. prstu - prsteníku, který je podle toho i v češtině označen. Latinsky je 4. prst též označován jako anularius (latinsky: z/od nebo vztahující se k pečetnímu prstenu). I dnes lidé nosí prsteny nejčastěji na prsteníku, i když už většinou nejsou pečetní. Ve způsobu nošení prstenů najdeme i odchylky a módní trendy, objevuje se nošení prstenu na jiném než proximálním článku, např. na prostředních a distálních článcích.

Je-li prsten nošen nejčastějším výše uvedeným způsobem, velikost prstenu vhodného pro nošení na určitém prstě závisí zejména na šírce prstu v oblasti kloubu mezi proximálním a prostředním článkem prstu (v případě palce mezi proximálním a distálním článkem). Nejdůležitějším rozměrem skeletu je báze (základna) prostředního článku (u palce distálního článku). Prsten se musí přes tento kloub relativně lehce navléknout a sundat, na druhou stranu ale nesmí při dolů svěšené ruce ani při pohybech ruky $\mathrm{z}$ prstu padat (Obr. 15). Pro každý prst tedy existuje relativně úzké rozpětí vnitřního průměru prstenu, který je pro něj vhodný a prakticky použitel-

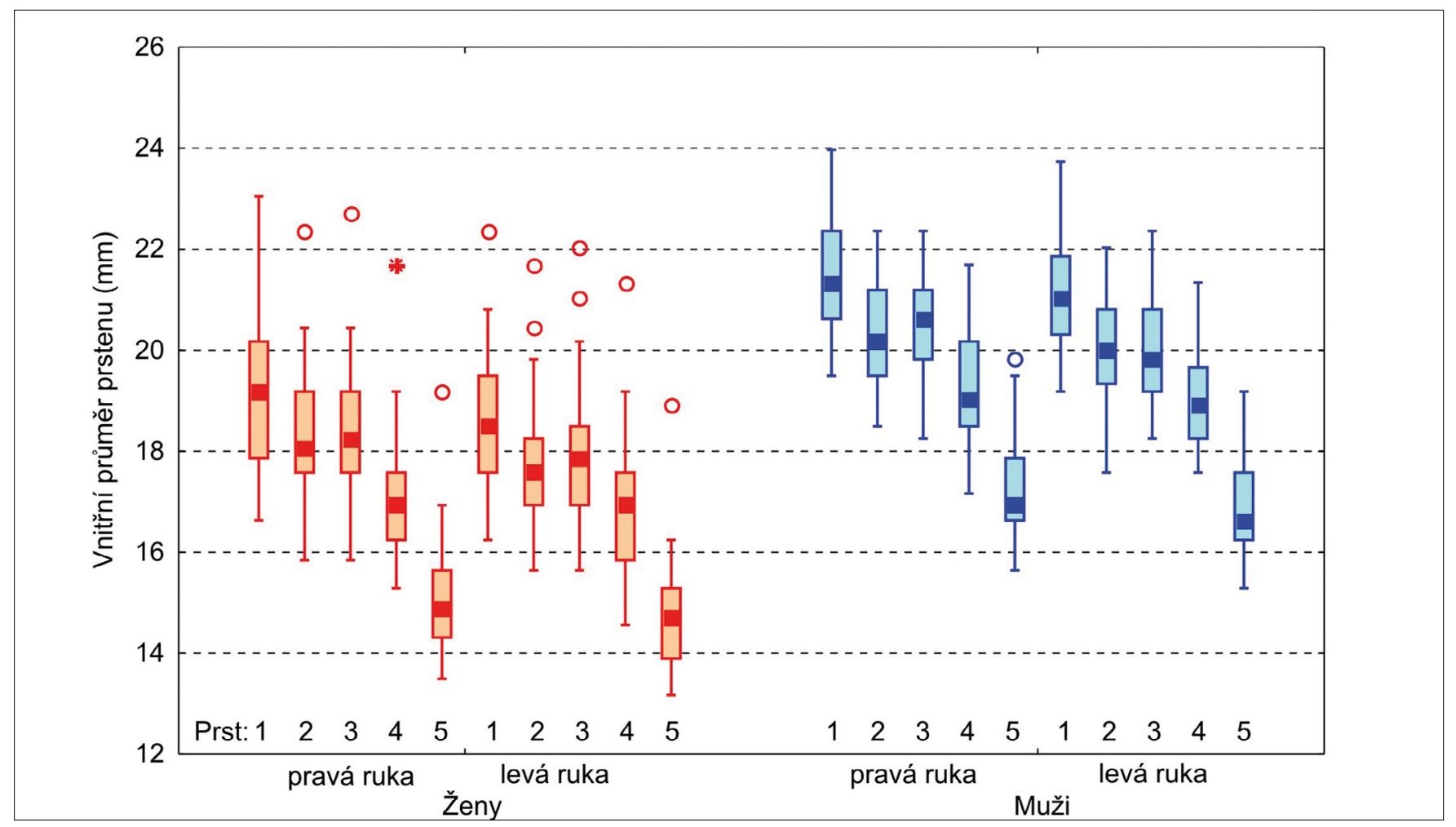

Obr. 16. Graf variability vnitřního průměru prstenů pro dospělé osoby (18 a více let) české populace, stanovený pomocí zlatnických kroužků (data převzata z práce Kadlecové 2006), vyjadřující rozdíl mezi pohlavími, pravou a levou rukou a jednotlivými prst; čtverec: medián, krabice: 25\%-75\% percentil; vousy: rozsah bez odlehlých hodnot, kolečka: odlehlé hodnoty, hvězdičky: extrémní hodnoty. 


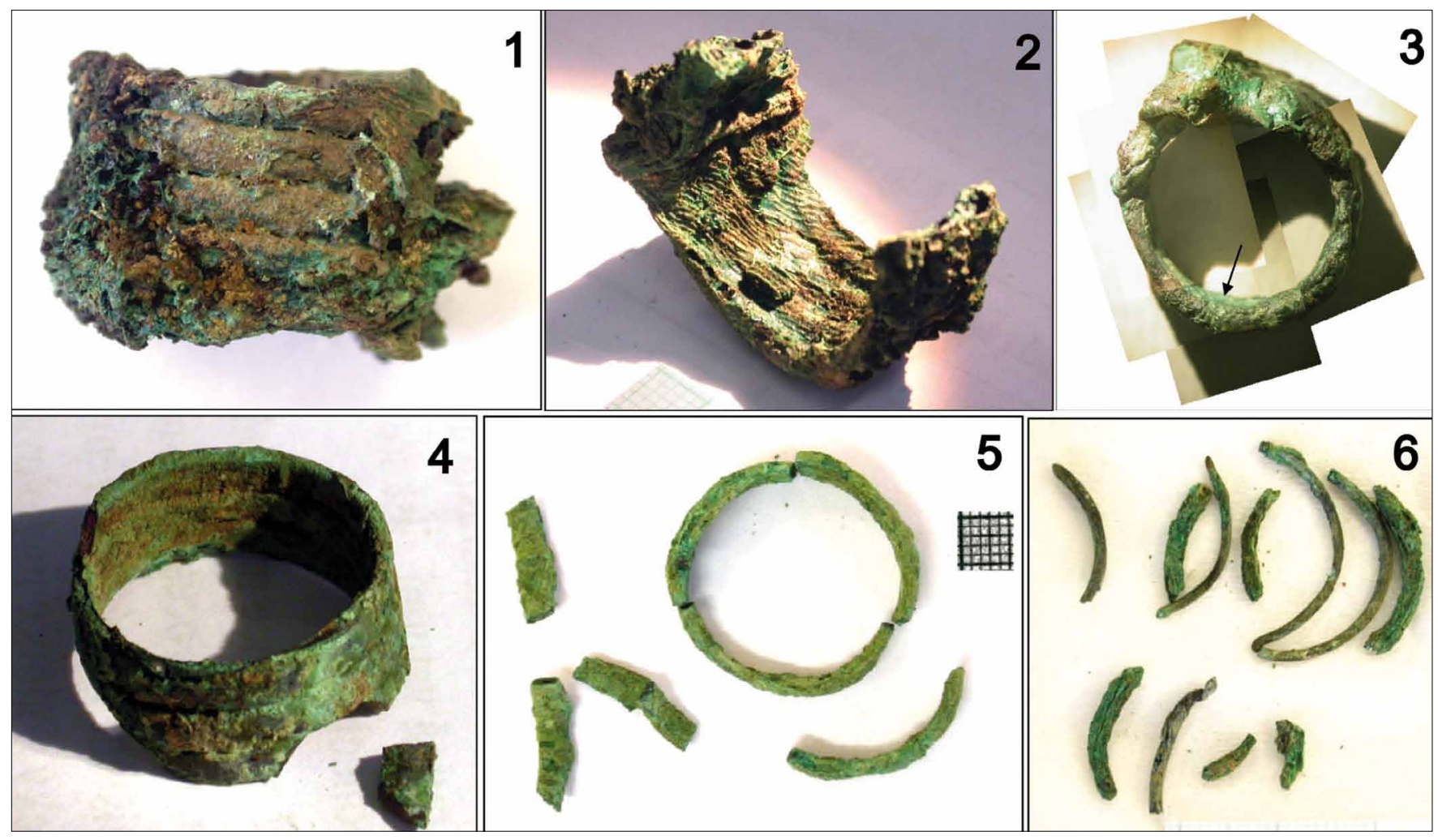

Obr. 17. Ukázka prstenů únětické kultury ze tří bohatě vybavených hrobů (č. 31, 32 a 38) z lokality Hulín I - U Isidorka (Peška et al. 2005, 2006). 1,2 - prsteny $\mathrm{z}$ hrobu staršího muže z hrobu č. 31, 3 - prsten z hrobu nedospělého jedince, pravděpodobně chlapce z hrobu 32 (složeno ze šesti snímků), 4, 5 a 6 - prsteny z hrobu mladé dospělé ženy z hrobu č. 38 .

ný. Studie na rentgenových snímcích ruky (Kadlecová 2008) ukázala, že šiŕku prstu v oblasti dotyčného kloubu prstu lze skutečně dobře odhadnout $\mathrm{z}$ největší šíŕky báze prostředního článku prstu v daném místě a lze tedy stanovit určitý rozsah vnitřních průměrů prstenů, které byly pro daný prst vhodné. Z antropometrických studií (Absolonová 2001; Kadlecová 2006, 2008) vyplývá, že existují výrazné rozdíly v průměru navlečeného prstenu, jak mezi jednotlivými prsty, tak mezi pohlavími a věkovými kategoriemi (Obr. 16). Nejmenší prsten lze navléct na malíček, největší je potřeba na palec. Muži mají v průměru silnější prsty a tomu musí odpovídat i prsteny. V průběhu postnatálního vývoje je ale v oblasti kloubu na prostředním článku prstu růstová chrupavka a kost zde není ještě plně vyvinutá do šírky. Proto mohou nedospělí do puberty (resp. ukončení růstu skeletu) prsteny navléknout snadněji a menších průměrů než po kompletní osifikaci prostředních článků prstů. $\mathrm{V}$ průběhu dospělosti mohou $\mathrm{v}$ důsledku pracovního zatížení nebo chorob prsty tloustnout a dříve nošené prsteny už nemusí svým průměrem dostačovat.

Z přehledu vytvořeného Kadlecovou $(2006,2008)$ se prsten $\mathrm{v}$ dnešním slova smyslu pravděpodobně objevuje až na počátku věku kovů a byl vyráběn $\mathrm{z}$ mědi, bronzu, stř́ibra a zlata. Vůbec nejrozšířenějším materiálem prstenů ve starší době bronzové byl bronz. Technologie výroby bronzu byla známa již v eneolitu (Sklenář et al. 2002, 42), kdy byl objeven vliv příměsí a př́ísad na vlastnosti bronzu (tvrdost, efektní barva) a jeho slévatelnost a zpracovatelnost.
Na základě archeologické literatury Kadlecová (2006, 30-31) vytvořila přehled prstenů ze starší doby bronzové ve střední Evropě, který obsahuje celkem 216 jednoznačně určitelných prstenů a 259 dalších artefaktů (z toho 110 kroužků) a jejich fragmentů, které by také mohly původně představovat prsteny. Prsteny zaznamenala v 85 hrobech, a také v depotech, celkem na 57 lokalitách. Kadlecová rozděluje prsten ve starší době bronzové do několika typů: (a) drátěný s kruhovým nebo oválným průřezem, tvořený prostým kroužkem (spojený, otevřený, s přeloženými konci, spirálový, spirálový se zduřenými konci, s růžicovitě stočenými konci, z dvojitého drátu se zpětnou kličkou), (b) páskový/plechový (otevřený s obloukovým průřezem, zavřený se čtvercovým nebo obloukovým průřezem, zavřený s trojúhelníkovým průřezem a konci spojenými nýty nebo nízkým nezdobeným segmentovým průřezem); (c) tyčinkový (otevřený s přiléhajícími zahrocenými konci, $s$ průřezem trojúhelníkovým, zaobleným, rombickým, kruhovým, se zduřenými nebo přeloženými konci), (d) drátěný se štítkem ve tvaru vrbového listu (nebo s konci zatočenými a přepojenými do kruhového štítku)a (e) dutý ze svinutého plechu. Př́klady prstenů z lokality Hulín I - U Isidorka (Peška et al. 2005) jsou uvedeny na obrázku 17. Většina prstenů však představují kroužky s jednoduchým točením. Materiálem byly nejčastěji měd’ a bronz, méně často zlato.

Funkce/důvody nošení prstenů ve společnosti starší doby bronzové je možné interpretovat/rekonstruovat na základě analogií z prvních starověkých civilizací, něco napovědět 


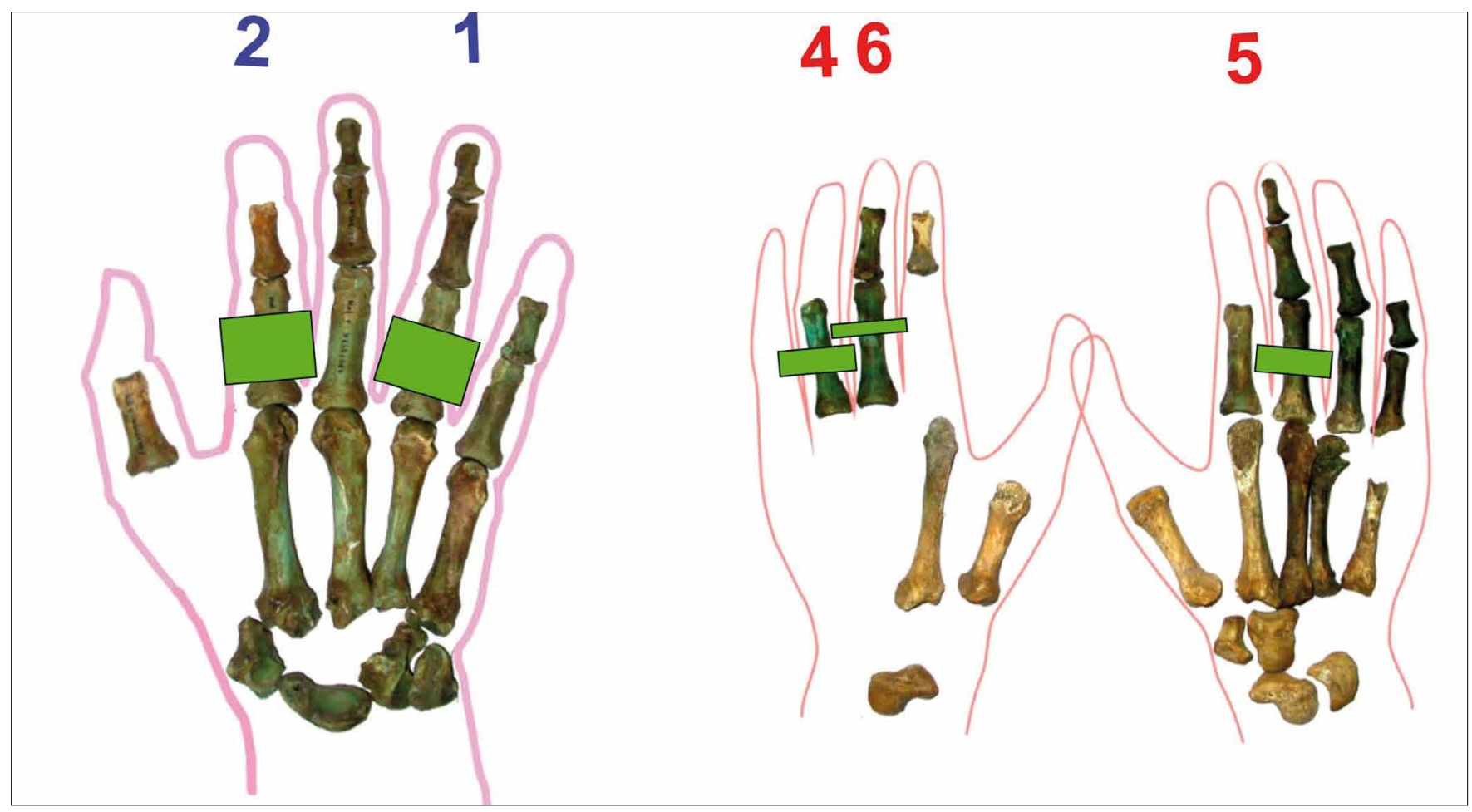

Obr. 18. Rekonstrukce navlečení prstenů na rukou u jedinců z lokality Hulín I; vlevo prsteny na ruce muže z hrobu č. 31, vpravo prsteny na rukou ženy z hrobu č. 38 .

může i způsob nošení prstenu (Kadlecová 2006). Podobně jako ostatní předměty z kovu mohly být ve společnosti starší doby bronzové kovové prsteny znakem určitého sociálního postavení. Jelikož kroužky mohly sloužit i jako forma předmincovního platidla, důležité pro rozlišení funkce/způsobu nošení šperku jsou (a) nálezy těchto šperků in situ př́mo na prstech (tj. pozitivní důkaz nošení), které dokumentují navlékání prstenů u zemřelých a (b) srovnání vnitřních průměrů potenciálních prstenů s reálným rozsahem tlouštky prstu, na který by se mohly hodit - negativní vymezení kroužků nevhodných jako prsteny - prŕliš malých nebo naopak př́lišs velkých).

Nejčastěji byly prsteny nalezeny „u těla zemřelého“, někdy $\mathrm{i}$ prrímo na prstu ruky a $\mathrm{v}$ těchto případech převažuje ruka pravá. Prsteny se častěji vyskytly v ženských hrobech než v mužských. Pokud bylo v jednom hrobě prstenů více, mohly mít prsteny i více závitů (výjimečně až 10 závitů), což svědčí o vyšším společenském postavení zemřelého.

Kadlecová (2006) rovněž v literatuře zaznamenávala rozměry prstenů a pokusila se srovnat vnitřní průměry prstenů ze starší doby bronzové s antropometrickými údaji o variabilitě vhodných prstenů u lidí dnešní české populace (56 žen, 52 mužů, věk 3-82 let, stanoveno nasazováním kalibrovaných zlatnických kroužků). Zjistila, že část údajů o „průměrech“ prstenů ze starší doby bronzové svým rozsahem výrazně převyšuje hodnoty pro dnešní populaci. Roli může hrát chybná interpretace předmětu původním autorem (nejde o prsten) a zejména to, že autoři jako „průměr“ prstenu často udávají zevní průměr, který nelze přímo vztahovat $\mathrm{k}$ rozměru prstu.
Vnitřní průměr prstenů ze starší doby bronzové Kadlecovou (2006) přímo změřené na originálních artefaktech však byl plně v rozsahu recentní variability. V další studii (Kadlecová 2008) autorka na základě rentgenových snímků vytvořila predikční pravidla pro odhad velikosti šírky prstu na základě šířky článků prstů. Následně tato pravidla použila pro odhad šířky prstů podle článků prstů nalezených v hrobech ze starší doby bronzové (z lokalit Hulín I a Franzhausen I) a srovnala takto získané odhady $\mathrm{s}$ vnitřními průměry prstenů $\mathrm{v}$ těchto hrobech nalezených (příklad Obr. 18). Výsledky ukazují, že rozměry prstenů skutečně odpovídají odhadům tlouštky prstů osob, na jejichž skeletu byly nalezeny.

Samotné nošení prstenu, a o to více také počet prstenů a jejich velikost či mohutnost, mohlo odrážet společenské postavení, sociální vliv či přímo majetek pohřbeného. Vzhledem $\mathrm{k}$ častějšímu výskytu prstenu v ženských hrobech bude tento aspekt asi výraznější u mužů. Na druhou stranu se u dvou masivních bronzových prstenů $\mathrm{z}$ bohatě vybaveného hrobu muže únětické kultury z Hulína I ukázalo, že jsou duté a byly vyrobeny z poměrně tenkého plechu (Peška et al. 2005, 2006). Je možné zde vidět snahu po náhražce masivního kusu bronzu méně nákladnou imitací? Byl to trend při běžném nošení prstenů (masivní prsteny jistě nebylo př́ijemné mít na ruce celý den, na rozdíl od tenkých kroužků), nebo se to týkalo jen pohřební výbavy? Na tyto otázky je zatím obtížné jednoznačně odpovědět.

Z hlediska prstenu jako symbolu kruhu není bez zajímavosti, že ve starší době bronzové, kdy se používala spirála jako součást výrobní technologie, měl spirálovitý prsten symbo- 


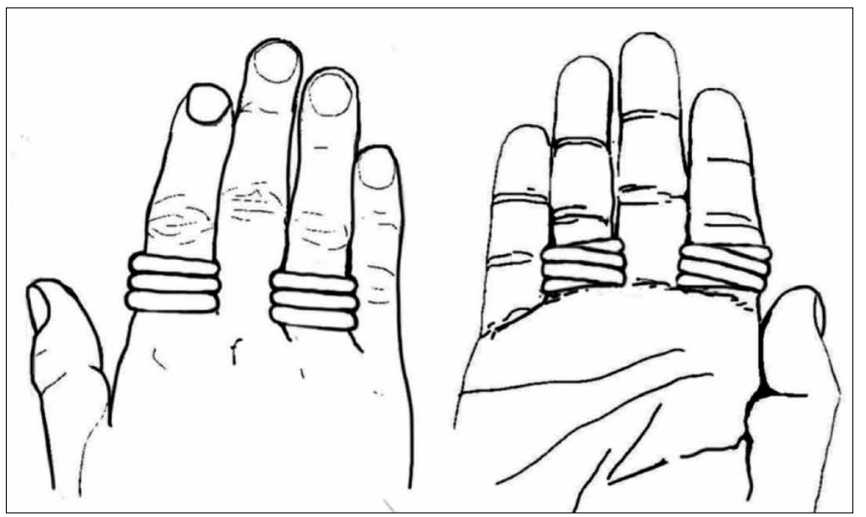

Obr. 19. Rekonstrukce otočení prstenů na prstech muže z hrbu č. 31, lokalita Hulín I (převzato z práce Peška et al. 2005). (Pozn.: Oproti skutečnému poměru prstenu a prstu je masivnost prstenů na rekonstrukci podhodnocena).

lizovat uzavřenost kruhu. Na několika prstenech únětické kultury z Hulína I (Peška et al. 2005) se díky korozním produktům mědi zachovaly uvnitř prstenu otisky dermatoglyfů článku prstů, na kterých byly prsteny navlečeny. Jelikož jsou dermatoglyfy pouze na dlaňové straně prstů, umožnilo nám to rekonstruovat otočení prstenů na prstě (Obr. 19). Zjistili jsme, že prsteny byly převážně otočeny tak, že konce spirály byly umístěny do dlaně a na zevně viditelném hřbetu ruky se prsteny jevily jako kruhové (Peška et al. 2005, 2006). Proto se domníváme, že už od samého počátku byla spirála vedlejším důsledkem používané technologie, ale prsten měl (tak jak to vyplývá $\mathrm{z}$ intepretace starých psaných textů) symbolizovat kruh.

Neméně zajímavé jsou ale i souvislosti symboliky prstenu a sexuality. Starořímský zvyk vyměňovat si prsteny mezi mužem a ženou při uzavírání manželství na znamení oboustranného závazku přešel i do svatebního obřadu křestanského. Nejprve byl prsten určen pouze ženě, později si ho vyměňovali oba partneři (Lurker 1999, 206; Malina 2007, 14-15). Prsten symbolizuje také sňatek biskupa s církví. Ve všech těchto případech se zpravidla navléká na 4 . prst. Navzdory pozdější kulturní diverzitě tvarů a forem prstenů i způsobů jejich nošení, kulturních synkrezí a v posledku vlivu obchodu, reklamy a módy (zdobná funkce šperků), které v dnešní době jakékoliv interpretace výrazně zamlžují, můžeme už na počátku vidět obě zmíněné tendence: (a) vyšší výskyt prstenů v ženských hrobech a (b) vazba prstenu k 4. prstu (je jistě otázkou, do jaké míry je to dáno praktickými ohledy - na 4. prstu pravděpodobně prsten nejméně zavazí při práci).

V přehledu pohlavně určených hrobů $\mathrm{z}$ doby bronzové (v geografickém prostoru dnešní České republiky) v práci Kalábkové (2013) se většina prstenů nacházela v hrobech ženských (29 kusů) a méně v hrobech mužských (8 kusů), i když je nutno podotknout, že nejvíce ve hrobech pohlavně neurčených (191 kusů). Pokud je prsten skutečně primárně symbolem manželského závazku (tj. společensky uznaného sexuálního přístupu partnerů k sobě navzájem), už od počátku se zde projevuje v lidských společnostech všeobecně rozšířená odlišné posuzování sexuální morálky u žen a mužů, pravidla jsou obvykle

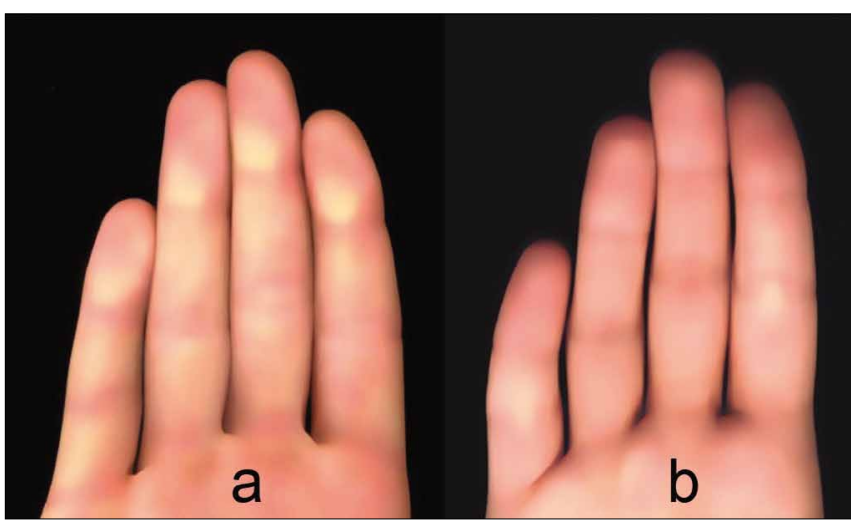

Obr. 20. Ruce s rozdílným poměrem 2. a 4. prstu: extrémně nízký (maskulinní) poměr (a) a extrémně vysoký (femininní) poměr (b).

přísnější pro ženu (nebot její partner může její nevěrou mnohem více ztratit než ona jeho nevěrou) a pro prsten - symbol závazku je určen především jí. Mužský prstem (jiný než svatební) pak může být původně analogicky symbolem mužova závazku vůči společnosti, např. symbolem nějaké funkce či úřadu.

Bez zajímavosti není ale ani to, že právě 4 . prst je při své diferenciaci a růstu $\mathrm{v}$ prenatálním období nejvíce ovlivněn poměrem testosteronu a estrogenů (Manning 2002, for review). Jeho relativní délka vůči 2. prstu, která se ustavuje už během prenatálního období, se považuje za ukazatel míry maskulinizace či feminizace, ovlivňující sexuální vlastnosti těla i chování člověka v dospělosti (Obr. 20). Vliv prenatálních pohlavních hormonů potvrdily i experimentální studie na myších (Zheng, Cohn 2011). V kognitivní studii mužské atraktivity (Roney, Maestripieri 2004) bylo dále zjištěno, že poměr délky 2. a 4. prstu souvisí s tím, jak ženy vnímají fyzickou atraktivitu muže. Čím nižší (tj. maskulinnější) byl u muže tento poměr, tím atraktivnější se muž ženám zdál během sociálního kontaktu a krátkého rozhovoru. Prenatální pohlavní hormony tedy maskulinizací zjevu a chování muže mění jeho atraktivitu pro ženy a současně upravují v daném smyslu i poměr délky prstů. V experimentální studii (Saino et al. 2006) bylo arteficiálními manipulacemi s délkou 2. a 4. prstu na obrázcích ruky zjištěno, že poměry délek prstů jsou podkladem atraktivity ruky samotné (tj. bez nutnosti vidět a setkat se s živým člověkem). Úprava délky prstů ve smyslu vyšších prenatálních hladin testosteronu (relativně delší 4. prst) zvyšovala atraktivitu mužské ruky pro ženy a úprava délek prstů ve smyslu nižších prenatálních hladin (relativně kratší 4. prst) naopak zvyšovala atraktivitu ženských rukou pro muže. A právě na 4 . prst si dodnes novomanželé vzájemně navlékají snubní prsteny na znamení svého (pohlavně specifického) partnerského závazku. Lze uvažovat o tom, že evolucí dané tendence k výběru sexuálně zralého a kompetentního partnera ovlivňovaly podvědomé vnímání sexuálně/reprodukčně podstatných vlastností podle ruky (muž žádá ženu „o ruku“) a symbolika navlékání prstenu je toho odrazem? Je možné, že to s jistotou nezjistíme nikdy... 


\section{DISKUSE A ZÁVĚRY (Miroslav Králík)}

Oblast archeologické antropologie ukazuje možnosti studia vztahu člověka a artefaktu na několika příkladech studií uskutečněných spoluautory této studie.

Vybraná dílčí témata dokumentují skutečnost, že artefakty, představující umělá vylepšení lidských možností, musí v různých aspektech "přivrácených" $\mathrm{k}$ člověku (fyzické rozměry, funkční adekvátnost, ekonomická dostupnost/přijatelnost, uskutečnitelnost $\mathrm{v}$ rámci vyměřeného času dne či života, energetická udržitelnost $\mathrm{z}$ hlediska výroby i užívání aj.) udržovat „lidský rozměr“ (člověk je mírou artefaktů), ale současně $\mathrm{v}$ aspektech odvrácených/směřujících od člověka (funkčnosti $\mathrm{v}$ různých rovinách) posouvá možnosti $\mathrm{z}$ hlediska technické účinnosti, efektivity práce, ekonomické výhodnosti, symbolické signalizace aj. daleko nad rámec možností života bez artefaktů. Artefakty svým připoutáním k člověku novými prostředky plní staré, evolučně dané funkce při získávání potravy, reprodukci, hájení teritoria, udržování sociálního systému aj., ale současně novými (technickými, organizačními, ekonomickými) prostředky vyvolávání dopady, které tyto funkce $\mathrm{z}$ řádu lidských „rozměrü“ vytrhují tím více, čím efektivnější a úspěšnější artefakty jsou.

V průběhu evoluce soužití člověka s arteficiálním světem, který si kolem sebe vytvořil, vedlo bezesporu k trvalým a nevratným změnám stavby lidského těla, fyziologických mechanismů, psychiky i myšlení, artefakty jsou součástí našeho (rozšířeného) fenotypu stejně, jako jsou drápy fenotypu lva nebo zobák fenotypu orla. V některých vlastnostech artefaktů lze tedy do určité míry vždy hledat všeobecné zákonitosti, dané biologickými limity člověka (velikost těla, energetický metabolismus, cirkadiánní a cirkanuální rytmy, výběr sexuálního partnera, sociální postavení, celoživotní zaměřenost), které najdeme prakticky $\mathrm{u}$ všech lidí všude na světě. $\mathrm{V}$ př́padě diference mezi lidskými skupinami v těchto vlastnostech artefaktů lze pak více či méně přesně usuzovat na rozdíly $\mathrm{v}$ těchto biologických vlastnostech nebo síle vazby těchto artefaktů $\mathrm{k}$ těmto vlastnostem (větší obuv znamená bud' větší chodidlo, tj. velikost těla, nebo menší nutnost přesně sedící/efektivně fungující obuvi). Na druhou stranu jsou ale současně (a právě naopak) artefakty natolik nositeli kulturních odlišností v použitém materiálu, způsobu zpracování, designu a finální formě, že se lidé různých kultur liší právě v nich a podle artefaktů se nejlépe odliší.

Bylo by jistě možné vybrat i jiné př́klady artefaktů, které provází člověka dějinami a na kterých je možné také sledovat tento proces (oděv, nádoba, projektil aj.) a hledat polohu artefaktů na průsečíku jejich biologických funkcí, symbolického významu a technologického pozadí. Př́kladem může být nádoba - artefakt asi nejčastěji v archeologii nacházený v obdobích od neolitu; objem džbánů kultury se šňůrovou keramikou nacházených v hrobech mužů a žen se v průměru liší. V ženských hrobech se nacházely džbány se střední hodnotou objemu okolo 1 litru, zatímco v mužských hrobech o střední hodnotě nad 2 litry (Krištuf 2005, 107). Jak autor uvádí v interpretaci, nelze vyloučit, že rozdíl ve velikosti džbánů byl pouze symbolický.
Nelze ovšem také vyloučit, že tyto rozdíly odráží biologický rozdíl mezi mužem a ženou v intenzitě energetického metabolismu a množství tekutiny, které běžně muži a ženy vypijí. Jiným př́kladem může být interpretace významu měděných zbraní v eneolitických hrobech a hrobkách v oblasti Italie (Dolfini 2011). Jsou tam nacházeny dýky, dýkovité sekery (anglicky halberds, německy Stabdolch na našem území se nevyskytují) a sekery. Trasologická analýza ukázala, že sekery sloužily k opracování dřeva a nesly jasné stopy takového užívání, dýky nesly stopy užívání při zabíjení a stahování dobytka (pravděpodobně za rituálních okolností), zatímco nožovité sekery byly zbraněmi k zasazování bodných ran (Dolfini 2011). Utilitární význam artefaktu nikterak nevylučoval jeho symbolickou funkci a použití jako milodar při pohřebním obřadu.

Stejný předmět lze tedy vnímat $\mathrm{v}$ mnoha rovinách, které se $\mathrm{v}$ „životě“ artefaktu vzájemně prolínají a ovlivňují. Jejich vzájemné interakce v konkrétních situacích (kulturách) a jejich srovnání nám teprve dovolují posoudit skutečné místo/roli studovaného artefaktu v lidském životě. Právě to jsme se pokusili na uvedených př́kladech vztahu artefaktu a člověka dokumentovat.

\section{LITERATURA}

Absolonová, Karolína (2001): Prsten v době hradištní. Ročníková práce. Brno: Masarykova univerzita.

Bárta, Patrick (2005): Výroba - meč z Blučiny. (online). http://www.templ. net/cesky/vyroba-mec_z_bluciny.php.

Conolly, P. (1992): Jak se žilo v minulosti - Dějiny ř́mského vojska. Bratislava: Fortuna Print.

Dolfini A. (2011): The function of Chalcolithic metalwork in Italy: an assessment based on use-wear analysis. Journal of Archaeological Science 38(5) 1037-1049.

Dostál, Bořivoj (1966): Slovanská pohřebiště ze střední doby hradištní na Moravě. Praha: Academia., str. 70 - 72.

Droberjar, Eduard (2001): Zlatý náramek typu Tournai - Blučina ze středních Čech. Archeologie ve středních Čechách, 5, 517-527.

Kadlecová, Dagmar (2006): Prsten ve starši době bronzové. Bakalářská práce. Brno: Masarykova univerzita.

Kadlecová, Dagmar (2008): Prsten a měkké tkáně ruky. Diplomová práce. Brno: Masarykova univerzita.

Kalábková, Kateřina (2013): Prsten v pravěku. Diplomová práce. Pardubice: Univerzita Pardubice.

Lurker, Manfred (1999): Slovník biblických obrazů a symbolů. Praha: Vyšehrad.

Malina, Jaroslav (2007): Úvodní slovo. In: Jaroslav Malina (ed.) Kruh prstenu: Světové dějiny sexuality, erotiky a lásky od počátkư do současnosti v reálném životě, krásné literatuře, výtvarném umění a dílech českých malírù a sochařu inspirovaných obsahem této knihy. Brno: Akademické nakladatelství CERM; Nakladatelství a vydavatelství NAUMA, s. 13-18.

Manning John T. (2002): Digit Ratio: A Pointer to Fertility, Behavior, and Health. Rutgers University Press.

Krištuf P. (2005): Džbány českého eneolitu. In: Neustupný E., John J. (eds.) Pŕíspěvky k archeologii 2. Plzeň: Katedra archeologie ZČU v Plzni, s. 69 $-126$.

Kuna, Martin (2013): Neústupná archeologie. S Evženem Neústupným o jeho životě v archeologii. Archeologické rozhledy, 65(2), 405-422.

Neústupný, Evžen (2010): Teorie archeologie. Plzeň.

Peška, J., Králík, M., Selucká, A. (2006). Rezidua a otisky organických látek v korozních produktech mědi a jejích slitin. Pilotní studie. Industrie starší doby bronzové. Památky archeologické, 97, 5-46.

Peška, J., Berkovec, T., Hložek, M., Krupa, P., Trojek, T., Drozdová, E., Koldínská, Z., Králík, M., Selucká, A. (2005): Dosavadní výsledky mezioborové 
spolupráce na nálezech ze starší doby bronzové v Hulíně - U Isidorka. Ročenka 2004 (s. 69-93). Olomouc: ACO.

Poláček, Lumír - Marek, Otto - Skopal, Rostislav (2000): Holzfunde aus Mikulčice. In: Poláček, Lumír, ed., Studien zum Burgwall von Mikulčice. Brno: Archäologisches Institut, 177-302.

Roney, J. R., Maestripieri, D. (2004): Relative digit lengths predict men's behavior and attractiveness during social interactions with women. Human Nature, 15(3), 271-282.

Rudnick, B. (2012): Das römische Militärlager »In der Borg« von Haltern am See. Die archäologischen Ausgrabungen 1997-2002. Ausgrabungen und Funde in Westfalen-Lippe, 11, 205-431.

Ruttkay, Alexander (1976): Waffen und Reiterausrüstung des 9. Bis zur ersten Hälfte des 14. Jahrhunderts in der Slowakei, Teil II. Slovenská archeológia, 24(2), 245-395.

Saino, N., Romano, M., Innocenti, P. (2006). Length of index and ring fingers differentially influence sexual attractiveness of men's and women's hands. Behavioral Ecology and Sociobiology, 60(3), 447-454.

Sklenáŕ, Karel, Sklenárová, Zuzana, Slabina, Miroslav (2002): Encyklopedie pravěku v Čechách, na Moravě a ve Slezsku. Praha: Nakladatelství Libri.

Unger, Josef (2005): Archeologická antropologie- co je, co není a proč. Český lid, 92(1), 69-72.

Unger, Josef (2008): Problematika hájitelnosti předvelkomoravských a velkomoravských hradeb. In: Bitka pri Bratislave v roku 907 a jej význam pre vývoj stredného Podunajska, Bratislava, 177-182.

Unger, Josef (2010): Experimentální rekonstrukce upínání ostruhy z 9. století. Živá archeologie. (Re)konstrukce a experiment v archeologii, 11, 130131.

Vegetius Renatus, F. (1977): Nárys vojenského umění. In: Antické válečné umění, Praha: Svoboda, 411-540.

Weber, Z. (1969): O třetím rozměru v archeologii. Sborník prací Filosofické fakulty brněnské university, E 14, 219-222.

Zheng, Z., Cohn, M. J. (2011): Developmental basis of sexually dimorphic digit ratios. Proceedings of the National Academy of Sciences, 108(39): $16289-16294$

\section{AUTOŘI}

Hylmarová, Milada (7. 12. 1989, Hradec Králové) je absolventkou magisterského studijního programu Antropologie na Ústavu antropologie Masarykovy university v Brně. Během svého studia se zaměřila na studium vztahu člověka a artefaktu.

Kontakt: hylmarova.milada@gmail.com

Mazáč, Martin (1. 4. 1990, Uherské Hradiště) je studentem doktorského studijního programu Antropologie na Ústavu antropologie Masarykovy university v Brně. Zaměřuje se na experimenty související s archeologií.

Kontakt: 358117@mail.muni.cz

Šenkýŕ, Miroslav (7. 7. 1991, Boskovice) je bývalým studentem bakalářského studijního programu Antropologie na Ústavu antropologie Masarykovy university v Brně a nynějším studentem Mendelovy university $\mathrm{v}$ Brně. Zaměřuje se na studium vztahu člověka a artefaktu.

Kontakt: senkyrm@gmail.com

Unger, Josef (11. 9. 1944, Brno), archeolog a kulturní antropolog, absolvent Katedry archeologie Filozofické fakulty Masarykovy univerzity. Profesorem antropologie byl jmenován v roce 2004. Ve výzkumné práci se zabývá především sídly a životem šlechty ve středověku, archeologií církevních objektů a antropologií pohřebního ritu. Publikoval u nás i v zahraničí mnoho vědeckých studií.

Kontakt: Prof. PhDr. Josef Unger, CSc., Ústav antropologie Př́rodovědecké fakulty Masarykovy univerzity v Brně, Vinařská 5, 60300 Brno, e-mail: unger@sci.muni.cz.

Králík, Miroslav (1973), antropolog; v současnosti působí jako docent Ústavu antropologie Př́rodovědecké fakulty Masarykovy univerzity. Zabývá se sexuálním dimorfismem u živého člověka a na kostř̌e člověka, a dále analýzou lidských stop na archeologických nálezech.

Kontakt: Ústav antropologie Př́rodovědecké fakulty Masarykovy univerzity, Kotlářská 2, 61137 Brno, e-mail: mirekkralik@seznam.cz 